\title{
Three Types of Neurochemical Projection from the Bed Nucleus of the Stria Terminalis to the Ventral Tegmental Area in Adult Mice
}

\author{
Takehiro Kudo, ${ }^{1,2}$ Motokazu Uchigashima, ${ }^{1}$ Taisuke Miyazaki, ${ }^{1}$ Kohtarou Konno, ${ }^{1}$ Miwako Yamasaki, ${ }^{1}$ \\ Yuchio Yanagawa, ${ }^{3,4}$ Masabumi Minami, ${ }^{2}$ and Masahiko Watanabe ${ }^{1,4}$ \\ ${ }^{1}$ Department of Anatomy, Hokkaido University Graduate School of Medicine, Sapporo 060-8638, Japan, ${ }^{2}$ Department of Pharmacology, Graduate School of \\ Pharmaceutical Sciences, Hokkaido University, Sapporo 060-0812, Japan, ${ }^{3}$ Department of Genetic and Behavioral Neuroscience, Gunma University \\ Graduate School of Medicine, Maebashi 371-8511, Japan, and ${ }^{4}$ Japan Science and Technology Agency, Core Research for Evolutional Science and \\ Technology, Sanbancho, Chiyoda-ku, Tokyo 102-0075, Japan.
}

Dopaminergic (DAergic) neurons in the ventral tegmental area (VTA) play crucial roles in motivational control of behaviors, and their activity is regulated directly or indirectly via GABAergic neurons by extrinsic afferents from various sources, including the bed nucleus of the stria terminalis (BST). Here, the neurochemical composition of VTA-projecting BST neurons and their outputs to the VTA were studied in adult mouse brains. By combining retrograde tracing with fluorescence in situ hybridization for $67 \mathrm{kDa}$ glutamate decarboxylase (GAD67) and vesicular glutamate transporters (VGluTs), VTA-targeting BST neurons were classified into GAD67-positive

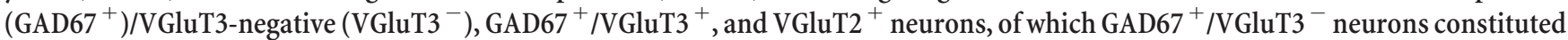
the majority ( $\sim 90 \%)$ of VTA-projecting BST neurons. GABAergic efferents from the BST formed symmetrical synapses on VTA neurons, which were mostly GABAergic neurons, and expressed $\mathrm{GABA}_{\mathrm{A}}$ receptor $\alpha 1$ subunit on their synaptic and extrasynaptic membranes. In the VTA, VGluT3 was detected in terminals expressing vesicular inhibitory amino acid transporter (VIAAT), plasmalemmal serotonin transporter, or neither. Of these, VIAAT ${ }^{+} / \mathrm{VGluT}^{+}{ }^{+}$terminals, which should include those from GAD $67^{+} / \mathrm{VGluT}^{+} \mathrm{BST}$ neurons, formed symmetrical synapses. When single axons from VGluT3 ${ }^{+}$BST neurons were examined, almost all terminals were labeled for VIAAT, whereas VGluT3 was often absent from terminals with high VIAAT loads. VGluT2 ${ }^{+}$terminals in the VTA exclusively formed asymmetrical synapses, which expressed AMPA receptors on postsynaptic membrane. Therefore, the major mode of the BST-VTA projection is GABAergic, and its activation is predicted to disinhibit VTA DAergic neurons. VGluT2 ${ }^{+}$and VGluT3 ${ }^{+}$BST neurons further $^{-}$ supply additional projections, which may principally convey excitatory or inhibitory inputs, respectively, to the VTA.

\section{Introduction}

The ventral tegmental area (VTA) is the source of dopaminergic (DAergic) neurons that project to the medial prefrontal cortex and nucleus accumbens, known collectively as the mesocorticolimbic dopamine system. Activity of DAergic neurons and dopamine release in target regions are crucial for motivational control of behaviors in response to value, salience, and alerting signals (Schultz et al., 1997; Bromberg-Martin et al., 2010). DAergic neurons are targets of modulation by various extrinsic afferents (Grace et al., 2007; Sesack and Grace, 2010; Morikawa and Paladini, 2011). In normal animals, the majority of DAergic neurons

Received Aug. 24, 2012; revised 0ct. 15, 2012; accepted 0ct. 25, 2012.

Author contributions: M.M. and M.W. designed research; T.K. and M.U. performed research; T.M., K.K., M.Y., Y.Y., and M.W. contributed unpublished reagents/analytic tools; T.K. and M.U. analyzed data; M.W. wrote the paper.

This study was supported in part through Grants-in-Aid for Scientific Research (24220007 to M.W.) and the Grant for "Integrated Research on Neuropsychiatric Disorders" performed under the Strategic Research Program for Brain Sciences (M.M. and M.W.), both provided by the Ministry of Education, Culture, Sports, Science, and Technology of Japan.

Correspondence should be addressed to Masahiko Watanabe, Department of Anatomy, Hokkaido University Graduate School of Medicine, Sapporo 060-8638, Japan. E-mail: watamasa@med.hokudai.ac.jp.

DOI:10.1523/JNEUROSCI.4057-12.2012

Copyright $(\underset{2}{ } 2012$ the authors $\quad 0270-6474 / 12 / 3218035-12 \$ 15.00 / 0$ are not spontaneously active because of GABAergic inhibition by projections from the ventral pallidum. This inactive state shifts into a tonic firing state by driving GABAergic neuronal firing in the nucleus accumbens, which, in turn, inhibits the ventral pallidum. Conversely, the pedunculopontine and laterodorsal tegmental nuclei in the brainstem play key roles in the initiation of the burst firing state of DAergic neurons. In addition, VTA DAergic neurons are locally innervated by VTA GABAergic neurons (Johnson and North, 1992; Omelchenko and Sesack, 2009), which also project to other brain regions (Van Bockstaele and Pickel, 1995; Steffensen et al., 1998; Carr and Sesack, 2000).

The bed nucleus of the stria terminalis (BST) is considered to be a relay nucleus in stress and reward pathways (Herman and Cullinan, 1997; Jalabert et al., 2009). The BST is strongly interconnected to the mediocentral amygdala and the shell of the nucleus accumbens, which together constitute the extended amygdala (Alheid and Heimer, 1988; Brog et al., 1993). Through projections to the paraventricular hypothalamic nucleus (PVN), VTA, and relay nuclei of the autonomic nervous system (Davis and Whalen, 2001), the BST and the central nucleus of the amygdala are involved in the expression of endocrine, auto- 
nomic, and somatic signs of stress responses and negative affective states, such as anxiety, fear, and aversion (Walker and Davis, 1997; Nijsen et al., 2001; Cecchi et al., 2002; Fendt et al., 2003; Sullivan et al., 2004; Deyama et al., 2008; Radley and Sawchenko, 2011). The BST is densely populated with GABAergic neurons (Cullinan et al., 1993), and there are also a few neurons expressing vesicular glutamate transporters (VGluTs) (Hur and Zaborszky, 2005; Jalabert et al., 2009; Poulin et al., 2009). Studies using in vivo electrophysiological recording have demonstrated a strong excitatory influence on VTA DAergic neurons by stimulation of the BST (Georges and Aston-Jones, 2001, 2002; Jalabert et al., 2009). However, there is a lack of clear information about neurochemical composition of, and innervation by, BST neurons projecting to the VTA.

In this study, we characterized VTA-projecting BST neurons using combined neurotracing and histochemical techniques and identified three neurochemical types of BST-VTA projection. The major projection originates from BST GABAergic neurons expressing $67 \mathrm{kDa}$ glutamate decarboxylase (GAD67) and preferentially targets VTA GABAergic neurons. There are also additional projections from VGluT2-expressing and VGluT3/ GAD67-coexpressing BST neurons, which likely represent excitatory and inhibitory projections, respectively, as suggested from their distinct postsynaptic morphology and receptor expression.

\section{Materials and Methods}

Animals and section preparation. All experiments were performed according to the guidelines laid down by the animal welfare committee of Hokkaido University and received institutional approval. In the present study, we used adult male C57BL/6 mice $(n=37)$ and GAD67-green fluorescent protein (GFP) ( $\Delta$ neo) mice (Tamamaki et al., 2003) $(n=6)$, which were termed hereafter GAD67-GFP knock-in mice. Under deep pentobarbital anesthesia (100 $\mathrm{mg} / \mathrm{kg}$ of body weight, i.p.), mice were fixed transcardially with $4 \%$ paraformaldehyde in $0.1 \mathrm{~m}$ sodium phosphate buffer (PB), pH 7.2, for light microscopy or 4\% paraformaldehyde/ $0.1 \%$ glutaraldehyde in PB for electron microscopy. Sections of fixed brains (50 $\mu \mathrm{m}$ in thickness) were prepared using a microslicer (VT1000S; Leica Microsystems) and subjected to free-floating immunohistochemistry. For fluorescence in situ hybridization, brains were freshly obtained under deep pentobarbital anesthesia and immediately frozen in powdered dry ice. Fresh-frozen sections $(20 \mu \mathrm{m})$ were cut on a cryostat (CM1900; Leica Microsystems). All sections were mounted on silanecoated glass slides.

For postembedding immunogold electron microscopy, microslicer sections $(400 \mu \mathrm{m})$ were cryoprotected with $30 \%$ glycerol in PB and frozen rapidly with liquid propane in the EM CPC unit (Leica Microsystems). Frozen sections were immersed in $0.5 \%$ uranyl acetate in methanol at $-90^{\circ} \mathrm{C}$ in the AFS freeze-substitution unit (Leica Microsystems), infiltrated at $-45^{\circ} \mathrm{C}$ with Lowicryl HM-20 resin (Chemische Werke Lowi), and polymerized under ultraviolet light. Ultrathin sections $(80 \mathrm{~nm})$ were prepared using an ultramicrotome (Ultracut; Leica Microsystems).

In situ hybridization. Digoxigenin (DIG)- or fluorescein-labeled cRNA probes were prepared to detect multiple mRNAs simultaneously. cDNA fragments of GAD67 [1036-2015; National Center for Biotechnology Information (NCBI) Reference Sequence NM_008077], mouse VGluT1 (301-1680; NCBI Reference Sequence BC054462), mouse VGluT2 (934-2060; NCBI Reference Sequence BC038375), and mouse VGluT3 (22-945; NCBI Reference Sequence NM_182959) were subcloned into the Bluescript II plasmid vector. Preparation of cRNA probes was performed as described previously (Yamasaki et al., 2010).

Sections were treated with the following incubation steps: acetylation with $0.25 \%$ acetic anhydride in $0.1 \mathrm{~m}$ triethanolamine- $\mathrm{HCl}, \mathrm{pH} 8.0$, for 10 min, and prehybridization for $1 \mathrm{~h}$ in hybridization buffer (50\% formamide, $50 \mathrm{~mm}$ Tris- $\mathrm{HCl}$, pH 7.5, 0.02\% Ficoll, $0.02 \%$ polyvinylpyrrolidone, $0.02 \%$ bovine serum albumin, $0.6 \mathrm{M} \mathrm{NaCl}, 200 \mu \mathrm{g} / \mathrm{ml} \mathrm{tRNA}, 1 \mathrm{~mm}$
Table 1. Primary antibodies used in the present study

\begin{tabular}{|c|c|c|c|c|}
\hline Molecule & Sequence (NCBI \#) & Host & Specificity & Reference \\
\hline Alexa Fluor 488 & & $\mathrm{Rb}$ & & Invitrogen (catalog \# A11094) \\
\hline $\mathrm{GABA}_{\mathrm{A}} \mathrm{R} \alpha 1$ & $\begin{array}{l}\text { 369-386 aа } \\
\text { (NM_010250) }\end{array}$ & GP & IB/HEK & Ichikawa et al. (2011) \\
\hline GFP & $\begin{array}{l}\text { 1-238 aа } \\
\text { (YP_002302326) }\end{array}$ & $\mathrm{Rb}$ & $\mathrm{Kl}$ & Takasaki et al. (2010) \\
\hline GluA1 & $\begin{array}{l}841-907 \text { aа } \\
\text { (X57497) }\end{array}$ & $\mathrm{Rb}$ & $\mathrm{IB} / \mathrm{KO}$ & $\begin{array}{l}\text { Yamazaki et al. (2010) } \\
\text { Yamasaki et al. (2011) }\end{array}$ \\
\hline HTT & $\begin{array}{l}\text { 1-77 aа } \\
\text { (AF013604) }\end{array}$ & $\mathrm{Rb}$ & IB & Somogyi et al. (2004) \\
\hline TH & & Ms-mAb & ${ }^{*} 1$ & Immunostar (catalog \#22941) \\
\hline VGluT2 & $\begin{array}{l}\text { 559-582 аa } \\
\text { (ВС038375) }\end{array}$ & $\mathrm{GP} / \mathrm{GO}_{0}$ & $\mathrm{IB}$ & $\begin{array}{l}\text { Miyazaki et al. (2003) } \\
\text { Miura et al. (2006) }\end{array}$ \\
\hline VGluT3 & $\begin{array}{l}\text { 558-601 aa } \\
\text { (AF510321) }\end{array}$ & GP & $*^{2} 2$ & Present study \\
\hline VIAAT & $\begin{array}{l}31-112 \text { аа } \\
\text { (BC052020) }\end{array}$ & $\mathrm{Rb} / \mathrm{G}_{0}$ & IB & $\begin{array}{l}\text { Miyazaki et al. (2003) } \\
\text { Fukudome et al. (2004) }\end{array}$ \\
\hline
\end{tabular}

aa, Amino acid residues; GluA1, ionotropic glutamate receptor subunit GluA1; Go, goat polyclonal antibody; GP, guinea pig polyclonal antibody; HEK, immunoblot with transfected HEK cell lysates; IB, immunoblot with brain homogenates; $\mathrm{KI}_{\text {, }}$ specific neuronal labeling in GAD67-GFP knock-in mice but not in wild-type mice; Ms-mAb, mouse monoclonal antibody; $\mathrm{KO}$, lack of immunolabeling in GluA1 knock-out brains; $\mathrm{Rb}$, rabbit polyclonal antibody; ${ }^{*} 1$, selective neuronal labeling and extensive overlap with dopamine transporter in the substantia nigra and VTA; ${ }^{*} 2$, specificity was confirmed by immunoblot and immunohistochemical patterns similar to previous VGluT3 antibodies raised against the corresponding sequence of rat VGluT3 (Somogyi et al., 2004) and selective labeling in cannabinoid receptor $\mathrm{CB}_{1}$-expressing GABAergic interneurons in the cortex, hippocampus, and amygdala (our unpublished data).

EDTA, and $10 \%$ dextran sulfate). Hybridization was performed at $63.5^{\circ} \mathrm{C}$ for $12 \mathrm{~h}$ in hybridization buffer supplemented with cRNA probes at a dilution of 1:1000. Posthybridization washing was done at $61^{\circ} \mathrm{C}$ successively with $5 \times$ SSC for $30 \mathrm{~min}, 4 \times$ SSC containing $50 \%$ formamide for 40 $\mathrm{min}, 2 \times$ SSC containing $50 \%$ formamide for $40 \mathrm{~min}$, and $0.1 \times$ SSC for $30 \mathrm{~min}$. Sections were incubated at room temperature in NTE buffer $(0.5$ $\mathrm{M} \mathrm{NaCl}, 0.01 \mathrm{~m}$ Tris-HCl, $\mathrm{pH}$ 7.5, and $5 \mathrm{~mm}$ EDTA) for $20 \mathrm{~min}, 20 \mathrm{~mm}$ iodoacetamide in NTE buffer for $20 \mathrm{~min}$, and TNT buffer $(0.1 \mathrm{~m}$ Tris$\mathrm{HCl}, \mathrm{pH} 7.5$, and $0.15 \mathrm{M} \mathrm{NaCl}$ ) for $20 \mathrm{~min}$.

For immunohistochemical detection of DIG and fluorescein, sections were blocked with DIG blocking solution [TNT buffer containing 1\% blocking reagent (Roche Diagnostics) and 4\% normal sheep serum] for $30 \mathrm{~min}$ and $0.5 \%$ tryamide signal amplification (TSA) blocking reagent (PerkinElmer Life and Analytical Sciences) in TNT buffer for $1 \mathrm{~h}$. Then sections were incubated with either alkaline phosphatase-conjugated sheep anti-DIG or anti-fluorescein antibody (1:500, 2 h; Roche Diagnostics) for chromogenic detection or peroxidase-conjugated anti-DIG or anti-fluorescein antibody (1:500, $2 \mathrm{~h}$; Roche Diagnostics) for fluorescence detection. After two TNT washes for $15 \mathrm{~min}$ each, chromogenic detection was performed using NBT/BCIP solution (1:50; Roche Diagnostics) in detection buffer $(0.1 \mathrm{M}$ Tris- $\mathrm{HCl}, \mathrm{pH} 9.5,0.1 \mathrm{M} \mathrm{NaCl}$, and 50 $\mathrm{mM} \mathrm{MgCl}_{2}$ ) for $12 \mathrm{~h}$, whereas fluorescence detection was done using the Cy3-TSA plus amplification kit (PerkinElmer Life and Analytical Sciences). In single or double fluorescence in situ hybridization, the first detection was performed with peroxidase-conjugated anti-fluorescein antibody (1:500, $1 \mathrm{~h}$; Invitrogen), followed by incubation with the FITCTSA plus amplification kit (PerkinElmer Life and Analytical Sciences). After inactivation of residual peroxidase activities by dipping sections in $3 \% \mathrm{H}_{2} \mathrm{O}_{2}$ for $30 \mathrm{~min}$, sections were subjected to second detection using DIG-labeled cRNA probe, peroxidase-conjugated anti-DIG antibody (1: 500, $2 \mathrm{~h}$; Invitrogen), and the Cy3-TSA plus amplification kit (PerkinElmer Life and Analytical Sciences). Finally, sections were counterstained with TOTO-3 (1:50 in PBS, 20 min; Invitrogen). To investigate the neurochemical composition of BST neurons, we used the shape of the lateral ventricle and anterior commissure as a landmark, took tiled images covering the BST $[20 \times$ magnifications, $1.3 \times$ zoom; two rows $(x$-axis) and three columns ( $y$-axis)], and counted the number of positive cells having the nucleus. For in situ hybridization combined with immunofluorescence, microslicer sections were subjected to incubation and detection for the former and then for the latter.

Immunofluorescence. In the present study, we used primary antibodies against Alexa Fluor $488, \mathrm{GABA}_{\mathrm{A}}$ receptor $\alpha 1$ subunit $\left(\mathrm{GABA}_{\mathrm{A}} \mathrm{R} \alpha 1\right)$, GFP, 

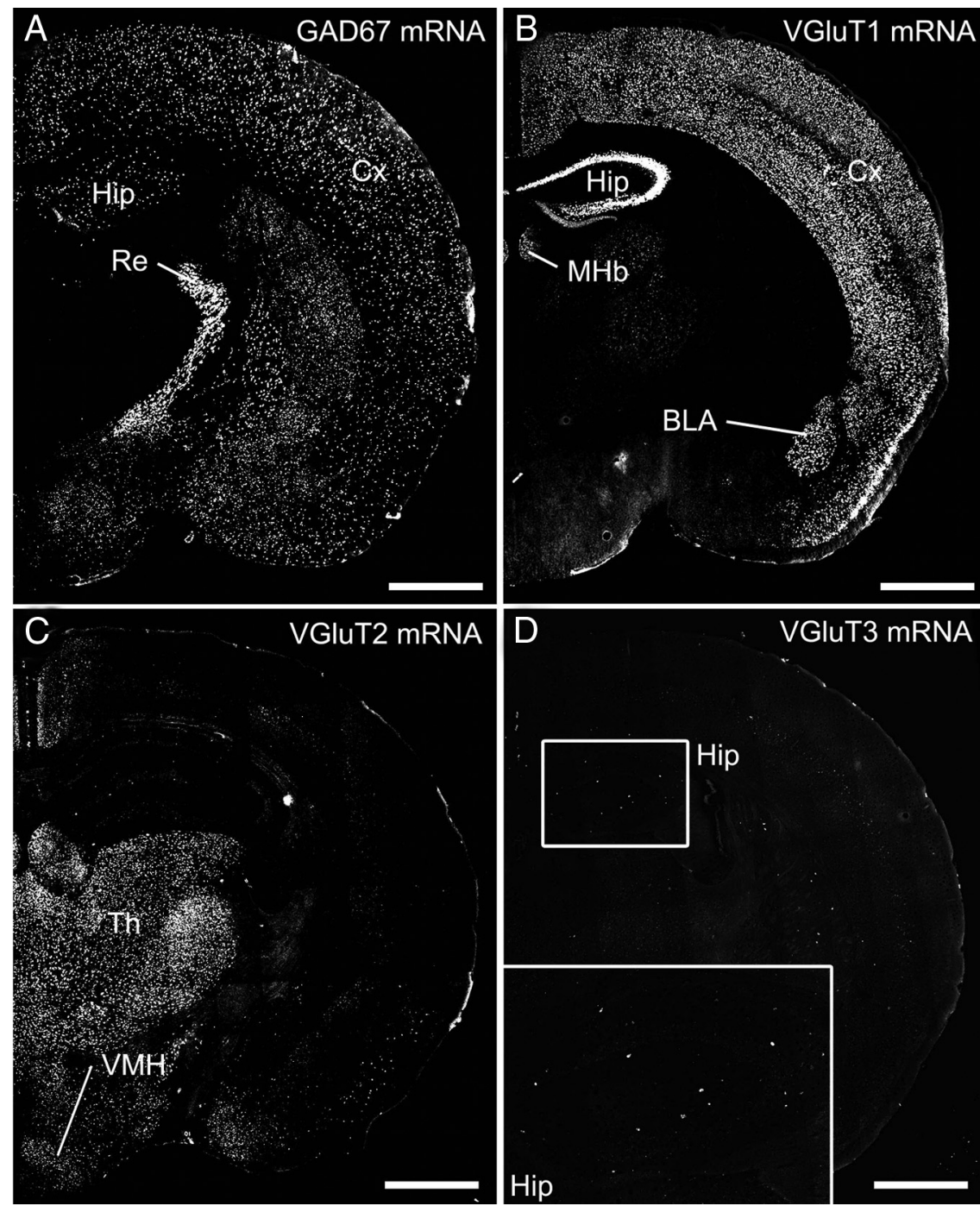

Figure 1. Fluorescence in situ hybridization showing characteristic labeling patterns with the use of antisense cRNA probes for GAD67 (A), VGluT1 (B), VGluT2 (C), and VGluT3 (D) mRNAs. Inset in D shows expression of VGluT3 mRNA in putative interneurons dispersed in the hippocampus. BLA, Basolateral amygdala; Cx, cerebral cortex; Hip, hippocampus; MHb, medial habenula; Re, reticular thalamic nucleus; Th, thalamus; VMH, ventromedial hypothalamic nucleus. Scale bars, $1 \mathrm{~mm}$.

AMPA-type glutamate receptor subunit GluA1, 5-hydroxytryptamine transporter (HTT), tyrosine hydroxylase (TH), VGluT2, VGluT3, and vesicular inhibitory amino acid transporter (VIAAT). Information on the antigen, host species, source, and specificity is summarized in Table 1. Of these primary antibodies, we produced goat and guinea pig antibodies against mouse VGluT3 (558-601 amino acid residues; GenBank accession number AF510321) using a glutathione $S$-transferase fusion protein according to a method reported previously (Watanabe et al., 1998). All immunohistochemical incubations were done at room temperature. Microslicer sections were incubated successively with $10 \%$ normal donkey serum for $20 \mathrm{~min}$, a mixture of primary antibodies overnight $(1 \mu \mathrm{g} / \mathrm{ml})$, and a mixture of Alexa Fluor 488-, Cy3-, or Cy5-labeled species-specific secondary antibodies for $2 \mathrm{~h}$ at a dilution of 1:200 (Invitrogen; Jackson ImmunoResearch).

Images were captured using a confocal laser-scanning microscope (FV1000; Olympus) equipped with a helium-neon/argon laser system. To avoid bleed-through into adjacent detection channels, Alexa Fluor 488, Cy3, and Cy5 were excited sequentially using the 488, 543, and 633 $\mathrm{nm}$ excitation laser lines, respectively, and emissions were collected using the spectral detection system configured with a galvanometer diffraction grating in combination with a variable slit for high-resolution wavelength separation. Images were acquired using a PlanApoN $(60 \times / 1.42$, oil immersion) objective lens (Olympus) with a $3 \times$ digital zoom and an appropriate pinhole to obtain 1 Airy unit for 496-508 nm emission wavelengths (optical section thickness, $1.0 \mu \mathrm{m}$ ). Images were captured using a confocal software (FV10-ASW, version 1.7; Olympus), digitized at 12-bit resolution into an array of $640 \times 640$ pixels (pixel size, $0.1 \mu \mathrm{m}$ ). For the specificity in multiple immunofluorescence, we confirmed the reproducibility of labeling with use of one primary antibody in the absence of the other and, whenever possible, by changing the host species of primary antibodies.

Retrograde and anterograde tracer labeling. We used Alexa Fluor 488-conjugated cholera toxin subunit b $(\mathrm{CTb})$ (Invitrogen) as a retrograde tracer and biotinylated dextran amine (BDA) (3000 molecular weight; Invitrogen) as an anterograde tracer. Eight C57BL/6 mice were used for the retrograde tracer experiment, and 11 C57BL/6 mice and five GAD67-GFP mice were used for anterograde tracer experiment. Under anesthesia with chloral hydrate $(350 \mathrm{mg} / \mathrm{kg}$ body weight, i.p.), a glass pipette (G-1.2; Narishige) filled with $1 \mu \mathrm{l}$ of $0.5 \%$ solution of Alexa Fluor $488-\mathrm{CTb}$ in saline was inserted stereotaxically into the VTA by the dorsal approach. Tracers were injected by air pressure at 10 psi with $5 \mathrm{~s}$ intervals for 1 min (Pneumatic Picopump; World Precision Instruments). After $2 \mathrm{~d}$ of survival, mice were anesthetized and fixed by transcardial perfusion. When combined with in situ hybridization, CTb-injected microslicer sections through the BST were first subjected to the fluorescence in situ hybridization protocol as described above. Because the fluorescence of Alexa Fluor 488-CTb became extinct after hybridization and the posthybridization wash, the tracer was detected by immunofluorescence with antiAlexa Fluor 488 antibodies, followed by incubation with Alexa Fluor 488-labeled anti-rabbit IgG for $2 \mathrm{~h}$. Images of double or triple fluorescence labeling were captured using a confocal laserscanning microscope. The number of labeled neurons in the BST was counted as described above.

We injected a $10 \%$ solution of BDA into the anterior part of the BST in wild-type or GAD67-GFP knock-in mice. After 4 d of survival, mice were anesthetized and fixed by transcardial perfusion. In combined labeling with immunofluorescence, BDA-injected microslicer sections through the VTA were incubated with a mixture of VIAAT and VGluT2 or VGluT3 antibodies, followed by incubation with fluorophore-conjugated secondary antibodies for $2 \mathrm{~h}$. Then, sections were incubated with Alexa Fluor 594-conjugated streptavidin (1:500 in PBS, $10 \mathrm{~min}$; Invitrogen). To investigate the neurochemical characteristic of BDA-labeled axon terminals in the VTA, we used the shape and location of the medial lemniscus and fornix as a landmark and took more than two images $(60 \times$ magnifications, $3 \times$ zoom $)$ of the medial and lateral parts of the VTA from each slice. For analysis, we counted VIAAT-positive $\left(\right.$ VIAAT $^{+}$), VGluT2 ${ }^{+}$, or VGluT3 ${ }^{+}$boutons whose center point matched with that of BDA labeling. To trace BDA-labeled axons, we acquired stacked images along the $z$-axis $(60 \times$ magnifications; at an interval of $0.5 \mu \mathrm{m}$ ) and collected BDA/VIAAT/VGluT3 ${ }^{+}$axons in which VIAAT and VGluT3 were detected in more than two boutons. The fluorescence intensity of VIAAT and VGluT3 at individual boutons on $\mathrm{BDA} / \mathrm{VIAAT} / \mathrm{VGluT3}^{+}$axons was measured and normalized using the mean fluorescence intensity obtained from $10 \mathrm{VIAAT}^{+}$or $10 \mathrm{VGluT} 3$ boutons, respectively, in the neighboring regions. The threshold value for high- or low-intensity groups was determined for each terminal marker 
A
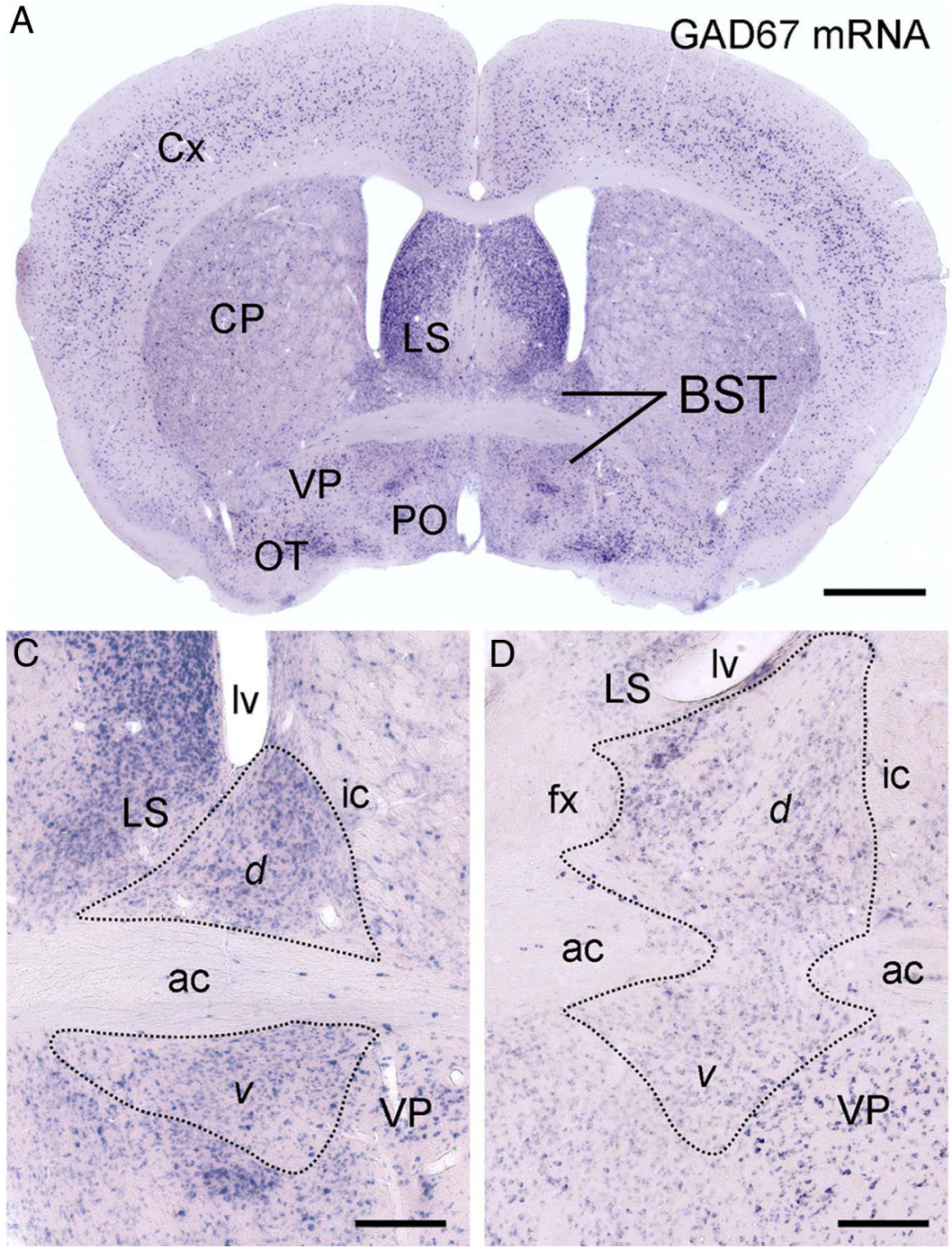
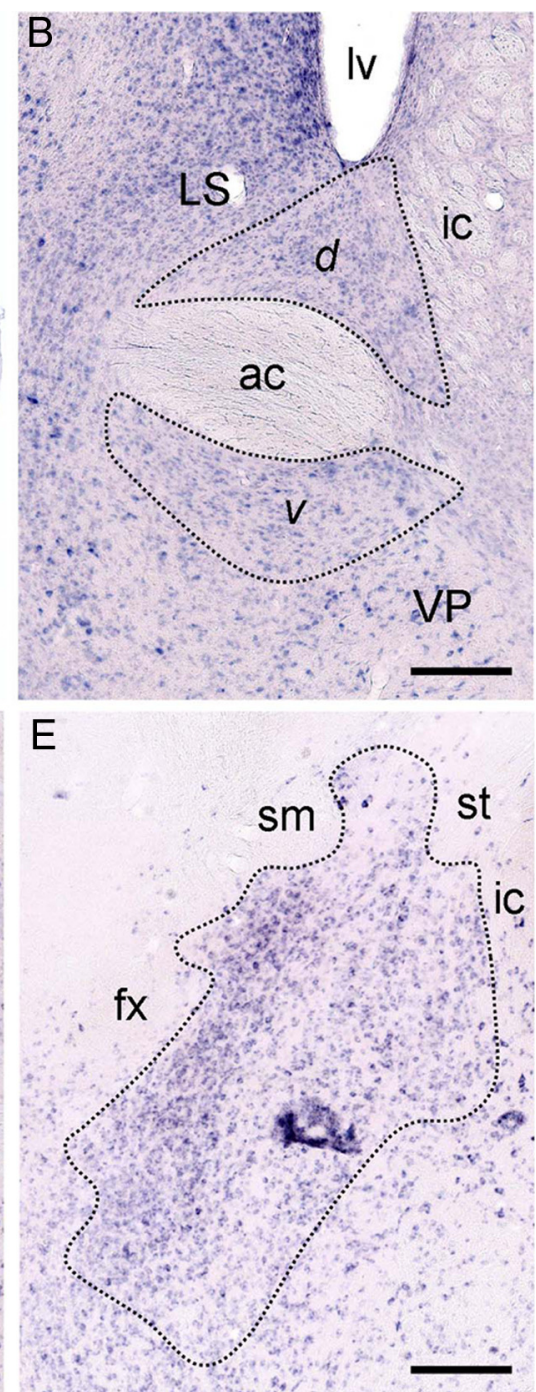

Figure 2. Chromogenic in situ hybridization showing GAD67 mRNA expression throughout the rostrocaudal extent of the BST. $A$, Low-power image of a coronal section through the anterior division of the BST. $\boldsymbol{B}-\boldsymbol{E}$, High-power images from the anterior $(\boldsymbol{B}-\boldsymbol{D})$ to the posterior $(\boldsymbol{E})$ division of the BST. $\boldsymbol{C}$ is an enlarged view of $\boldsymbol{A}$. The BST is surrounded by the caudate-putamen (CP), lateral septum (LS), preoptic area (PO), and ventral pallidum (VP). The anterior division of the BST is subdivided into the dorsal (d) and ventral (v) parts by the anterior commissure (ac). CX, Cerebral cortex; $\mathrm{fx}$, fornix; ic, internal capsule; Iv, lateral ventricle; $0 \mathrm{~T}$, olfactory tubercle; sm, stria medullaris; st, stria terminalis. Scale bars: $\boldsymbol{A}, 1 \mathrm{~mm} ; \boldsymbol{B}-\boldsymbol{E}, 200 \mu \mathrm{m}$.

according to the discriminant analysis method; the two groups were divided so that separation metrics, i.e., the ratio of between-class variance to within-class variance, became maximal. The statistical significance of the difference in the mean relative intensity of one transporter between high and low groups with that of the other was evaluated by MannWhitney $U$ test.

Electron microscopy. Preembedding silver-enhanced immunogold electron microscopy was conducted for naive or BDA-injected microslicer sections. First, sections were incubated in blocking solution for goat gold conjugates (Aurion) for $30 \mathrm{~min}$ and then with primary antibodies (rabbit anti-VIAAT, guinea pig anti-VGluT2, rabbit anti-HTT, mouse anti-TH, rabbit anti-GFP, or guinea pig anti-GABA $\mathrm{R} \alpha 1$ ) diluted with $1 \% \mathrm{BSA} / 0.004 \%$ saponin/PBS overnight. Secondary antibodies linked to $1.4 \mathrm{~nm}$ gold particles (1:200; Nanogold; Nanoprobes) were incubated for $2 \mathrm{~h}$, and immunogold particles were intensified using a silver enhancement kit (R-Gent SE-EM; Aurion). Next, BDA-labeled sections were incubated overnight with peroxidase-linked streptavidin and visualized with 3,3'-diaminobenzidine (DAB). Naive sections were incubated overnight with the guinea-pig anti-VGluT3 antibody, followed by immunoreactions with biotinylated donkey anti-guinea pig for $2 \mathrm{~h}$ and visualization with DAB. Sections were further treated with $1 \%$ osmium tetroxide for $15 \mathrm{~min}$, stained with $2 \%$ uranyl acetate for $20 \mathrm{~min}$, dehydrated, and embedded in Epon 812. Ultrathin sections containing the
VTA and its neighboring medial lemniscus were cut and photographed under an H-7100 electron microscope (Hitachi).

We used double-labeling postembedding immunogold electron microscopy using primary antibodies derived from different host species. Ultrathin sections on nickel grids were etched with saturated sodiumethanolate solution for 1-5 s. Then, sections were incubated using the two-step method. In the first labeling step, sections were incubated with $50 \mathrm{~mm}$ glycine in incubation solution $[0.1 \%$ Triton X-100 in Trisbuffered saline, $\mathrm{pH} 7.4$ (TBST)] for $10 \mathrm{~min}$, blocking solution containing $2 \%$ normal goat or rabbit serum (Nichirei) in TBST for $20 \mathrm{~min}$, primary antibody (rabbit or guinea pig GluA1 or $\mathrm{GABA}_{\mathrm{A}} \mathrm{R} \alpha 1$ antibody; $20 \mu \mathrm{g} /$ $\mathrm{ml}$ ) diluted with blocking solution overnight, and colloidal gold (10 $\mathrm{nm})$-conjugated anti-rabbit or anti-guinea pig $\operatorname{IgG}(1: 100$; British BioCell International) diluted with blocking solution containing $5 \mathrm{mg} / \mathrm{ml}$ polyethyleneglycol for $2 \mathrm{~h}$. After extensive washing in TBST, the second immunoreaction was repeated using rabbit or goat anti-VIAAT or guinea-pig or goat anti-VGluT2 antibody $(20 \mu \mathrm{g} / \mathrm{ml})$ and colloidal gold $(15 \mathrm{~nm})$-conjugated anti-rabbit or anti-guinea-pig IgG (1:100; British BioCell International). Finally, grids were washed in TBST for $15 \mathrm{~min}$, fixed with $1 \% \mathrm{OsO}_{4}$ in $\mathrm{PB}$ for $15 \mathrm{~min}$, and stained with $5 \%$ uranyl acetate in $40 \%$ ethanol for $90 \mathrm{~s}$, followed by Reynold's lead citrate solution for 90 s. Photographs were taken under an H-7100 electron microscope (Hitachi). For quantitative analysis, postsynaptic membrane-associated 

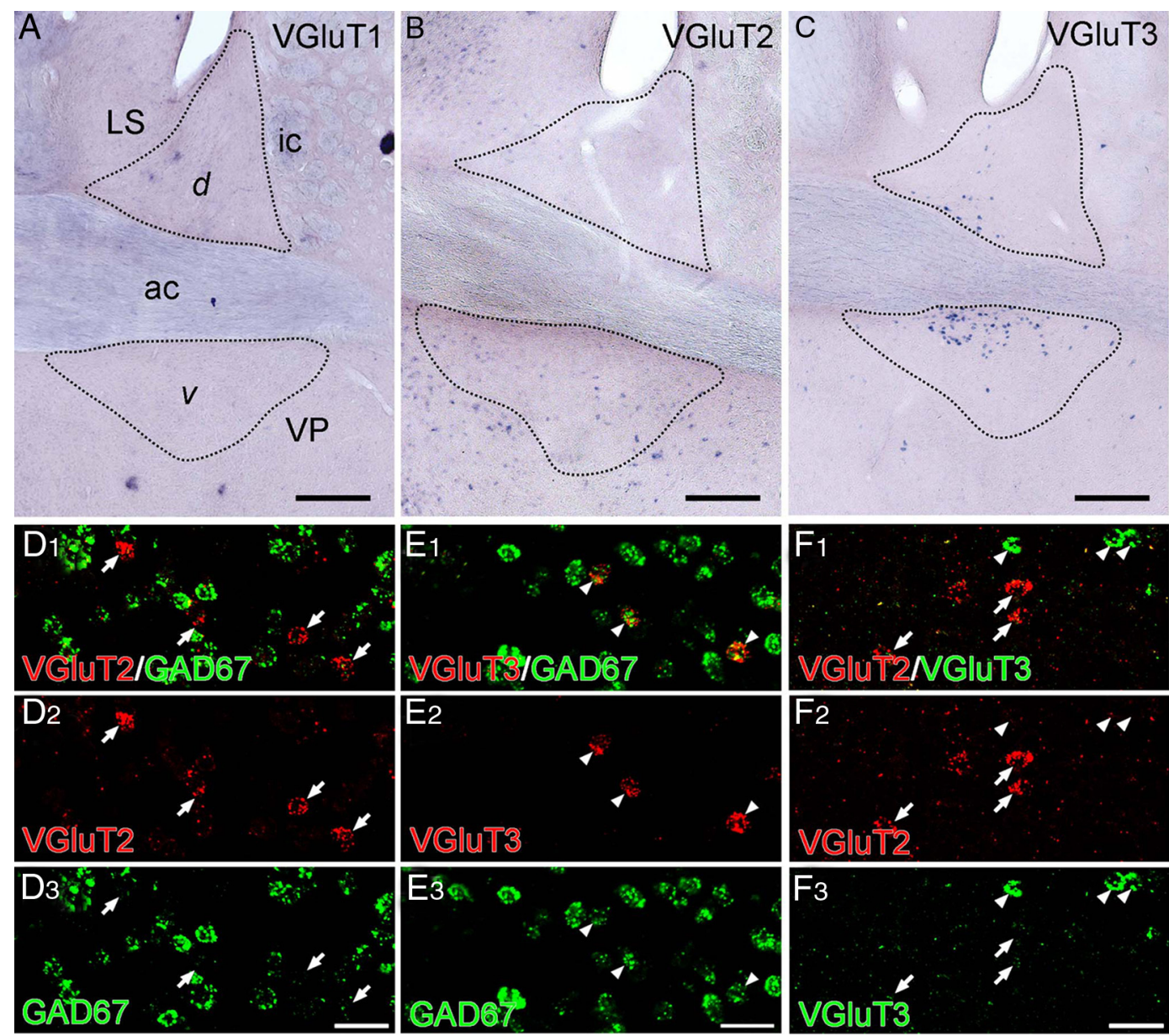

Figure 3. Distinct expression patterns of VGluT1-VGluT3 mRNAs in the anterior division of the BST. A-C, Chromogenic in situ hybridization for VGluT1 (A), VGluT2 (B), or VGluT3 (C) mRNAs. D-F, Double fluorescence in situ hybridization for VGluT2 (red) and GAD67 (green) mRNAs (D), VGluT3 (red) and GAD67 (green) mRNAs (E), and VGluT2 (red) and VGluT3 (green) mRNAs (F). No BST neurons express VGluT1 mRNA ( $\boldsymbol{A})$. VGluT2 mRNA is expressed in a small population of BST neurons ( $\boldsymbol{B}$ ), but these neurons lack hybridization signals for GAD67 mRNA (arrows in $\boldsymbol{D}$ ) or VGluT3 mRNA (arrows in $\boldsymbol{F}$ ). VGluT3 mRNA is expressed in a small population of BST neurons $(\boldsymbol{C}$ ), which coexpress GAD67 mRNA (arrowheads in $\boldsymbol{E}$ ), but not VGluT2 mRNA (arrowheads in $\boldsymbol{F}$ ). For abbreviations, see Figure 2. Scale bars: $\boldsymbol{A}-\boldsymbol{C}, 200 \mu \mathrm{m} ; \boldsymbol{D}-\boldsymbol{F}, 30 \mu \mathrm{m}$.

immunogold particles, being defined as those $<35 \mathrm{~nm}$ from the cell membrane, were counted on scanned electron micrographs and analyzed using MetaMorph software (Molecular Devices).

\section{Results}

\section{Neurochemical composition of BST neurons}

The BST has been shown to consist mostly of GABAergic neurons (Cullinan et al., 1993) with a few glutamatergic neurons expressing VGluT2 or VGluT3 mRNA (Hur and Zaborszky, 2005; Jalabert et al., 2009; Poulin et al., 2009). To quantify the neurochemical composition, we used fluorescence and chromogenic in situ hybridization for GAD67 mRNA as a marker for GABAergic neurons and vesicular glutamate transporters VGluT1VGluT3 as markers for glutamatergic neurons (Figs. 1-3). The specificity of each cRNA probe was verified by characteristic expression in coronal forebrain sections with the use of antisense cRNA probes (Fig. 1) and the lack of signals with the use of sense probes (data not shown). In brief, the antisense GAD67 cRNA probe labeled a small population of neurons dispersed in the cerebral cortex and hippocampus and almost all neurons in the reticular thalamic nucleus (Fig. 1A). Conversely, the three VGluTs displayed distinct distributions, as reported previously (Fremeau et al., 2004; Takamori, 2006).
The expression patterns of VGluT1 and VGluT2 mRNAs were complementary; the former predominated in the cerebral cortex, hippocampus, and basolateral amygdala (Fig. 1B), whereas the latter predominated in the thalamus and hypothalamus (Fig. 1C). Signals for VGluT3 mRNA were scattered in the cerebral cortex and hippocampus (Fig. 1D).

The BST is surrounded by the caudate-putamen, lateral septum, preoptic area, and ventral pallidum (Fig. 2A). Neurons expressing GAD67 mRNA were densely distributed throughout the rostrocaudal extent of the BST (Fig. 2B-E). Expression of GAD67 mRNA was observed in both the dorsal and ventral parts of the anterior BST division (Fig. $2 B-D$ ). In contrast, no BST neurons expressed VGluT1 mRNA, whereas a few expressed VGluT2 or VGluT3 mRNA (Fig. 3A-C). Consistent with previous reports (Hur and Zaborszky, 2005; Poulin et al., 2009), neurons expressing VGluT2 mRNA were more common in the posterior BST division (data not shown) than in the anterior division (Fig. 3B). VGluT3 mRNA was expressed in both the dorsal and ventral parts of the anterior BST division (Fig. $3 C$ ), as suggested by Jalabert et al. (2009). After double fluorescence in situ hybridization in the anterior BST division, no VGluT2 mRNA-expressing BST neurons ( $n=87$ from two mice) were labeled for GAD67 mRNA $(n=3059$; Fig. $3 D)$. Conversely, all VGluT3 mRNA-expressing 
BST neurons ( $n=144$, three mice) coexpressed GAD67 mRNA, and these constituted $6.6 \%$ of the total number of GAD67 mRNA-expressing neurons $(n=2175$; Fig. 3E). Expression of VGluT2 and VGluT3 mRNAs in distinct neuronal populations was confirmed by their nonoverlapping patterns (two mice; Fig. $3 F$ ). When counting BST neurons from sections subjected to double labeling for GAD67 and VGluT2 mRNAs, the ratio of neurons expressing GAD67 or VGluT2 mRNA was 100:3. Based on these scores, the relative proportions of GAD67 ${ }^{+} /$VGluT3negative $\left(\mathrm{VGluT3}^{-}\right)$, GAD67 ${ }^{+} / \mathrm{VGluT}^{+}$, and VGluT2 ${ }^{+}$neurons among BST neurons expressing either GAD67 mRNA or any of the three VGluT mRNAs were estimated to be 90,7 , and $3 \%$, respectively.

\section{Neurochemical composition of VTA-} projecting BST neurons and terminals We then quantitatively analyzed BST neurons projecting to the VTA by injecting the retrograde tracer CTb into the VTA (Fig. 4A). After confirming successful injection into the VTA (Fig. 4B), we examined coronal BST sections by fluorescence in situ hybridization for GAD67, VGluT2, or VGluT3 mRNA (Fig. 4A). CTb-labeled neurons densely populated the dorsal and ventral parts of the anterior BST division as well as the ventral pallidum (Fig. 4C). In the anterior BST division, $94.3 \%$ of all CTb-labeled neurons ( $n=508$, three mice) expressed GAD67 mRNA, and $24.7 \%$ of all GAD67 mRNA-expressing BST neurons $(n=1940$, three mice) were labeled with CTb (Fig. 4D). Conversely, $4.3 \%$ of all CTb-labeled neurons expressed VGluT2 mRNA ( $n=1604$, three mice; Fig. $4 E$ ), and $3.7 \%$ expressed VGluT3 mRNA ( $n=1068$, five mice; Fig. $4 F$ ). Considering that all BST neurons expressing VGluT3 mRNA coexpressed GAD67 mRNA, the majority ( $~ 90 \%)$ of VTA-projecting BST neurons are $\mathrm{GAD} 67^{+} /$ VGluT3 $^{-}$neurons, with the rest being either $\mathrm{GAD} 7^{+} /$VGluT3 $^{+}$neurons $(3.7 \%)$ or VGluT2 ${ }^{+}$neurons $(4.3 \%)$.

The neurochemical composition of BST neuron terminals in the VTA was examined by injecting the anterograde tracer BDA into the anterior BST division and performing immunofluorescence microscopy for VGluT2, VGluT3, and the inhibitory terminal marker VIAAT on coronal VTA sections (Fig. $5 A)$. Only successful cases of BDA injection into the BST were analyzed (Fig. 5B). In double immunofluorescence experiments for VIAAT and VGluT2, $\mathrm{VIAAT}^{+} / \mathrm{VGluT}^{-}{ }^{-}$terminals (Fig. 5C, arrowheads) constituted $93.1 \%$ of all BDA-labeled terminals examined ( $n=173$, two mice), whereas VIAAT $^{-}$/ VGluT2 $^{+}$(arrows) terminals comprised $4.6 \%$ (Fig. $5 E$ ). Similar results were obtained from double immunofluorescence experiments for VIAAT and VGluT3, in which $\mathrm{VIAAT}^{+}$/
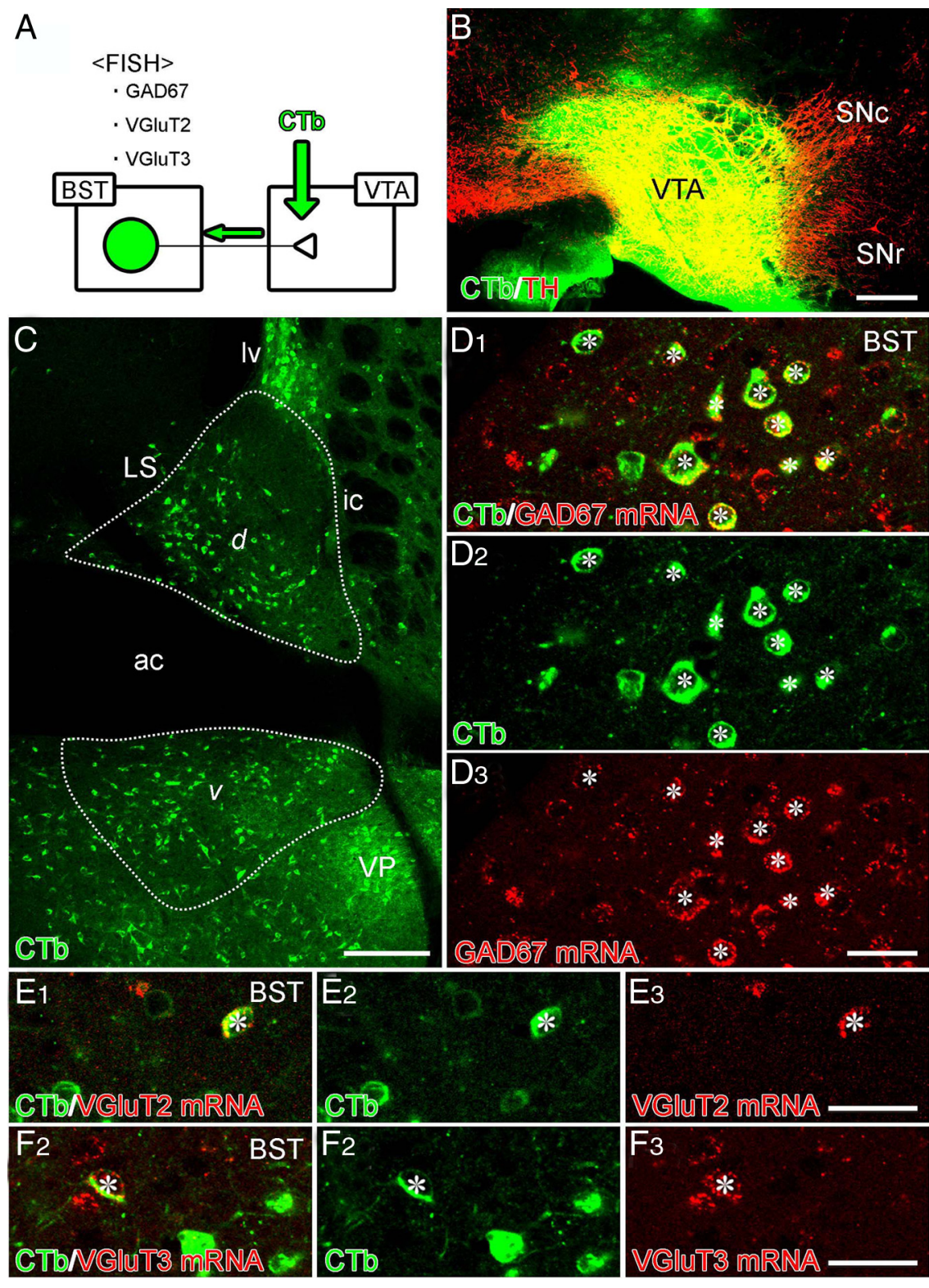

Figure 4. Combined retrograde tracer labeling and fluorescence in situ hybridization (FISH) showing neurochemical composition of BST neurons projecting to the VTA. $A$, Experimental diagram. $B$, Injection site of Alexa Fluor 488 -CTb (green) in the VTA. This section is immunostained for TH (red) to label DAergic neurons in the VTA and substantia nigra pars compacta (SNc). C, RetroVGluT3 $(\boldsymbol{F}) \mathrm{mRNA}(\mathrm{red})$. Asterisks indicate double-labeled cells. SNr, Substantia nigra pars reticulata. For other abbreviations, see Figure 2. Scale bars: $\boldsymbol{B}, \boldsymbol{C}, 200 \mu \mathrm{m} ; \boldsymbol{D}-\boldsymbol{F}, 30 \mu \mathrm{m}$.
VGluT3 $^{-}$(Fig. 5D, arrowheads) and VIAAT ${ }^{+} / \mathrm{VGluT3}^{+}($arrows) terminals comprised 94.8 and $3.5 \%$, respectively, of the BDA-labeled terminals examined $(n=229$, four mice; Fig. $5 F)$. In this experiment, we encountered a few $\mathrm{VIAAT}^{+} /$ VGluT2 ${ }^{+}$terminals $(2.3 \%$ of BDA-labeled terminals; Fig. $5 E$ ) and VIAAT $^{-} /$VGluT3 $^{+}$terminals $(1.7 \%$; arrows in Fig. $5 D, F)$, but the reason for these unexpected combinations remains unknown.

Each of the three neurochemical subtypes of BST neurons projects to the VTA in proportion to their population size in the BST. This indicates that the major projection in the BST-VTA pathway is derived from $\mathrm{GAD} 7^{+} / \mathrm{VGluT3}^{-}$BST neurons with additional projections from VGluT2 ${ }^{+}$and $\mathrm{GAD} 7^{+} / \mathrm{VGluT}^{+}{ }^{+}$neurons. 

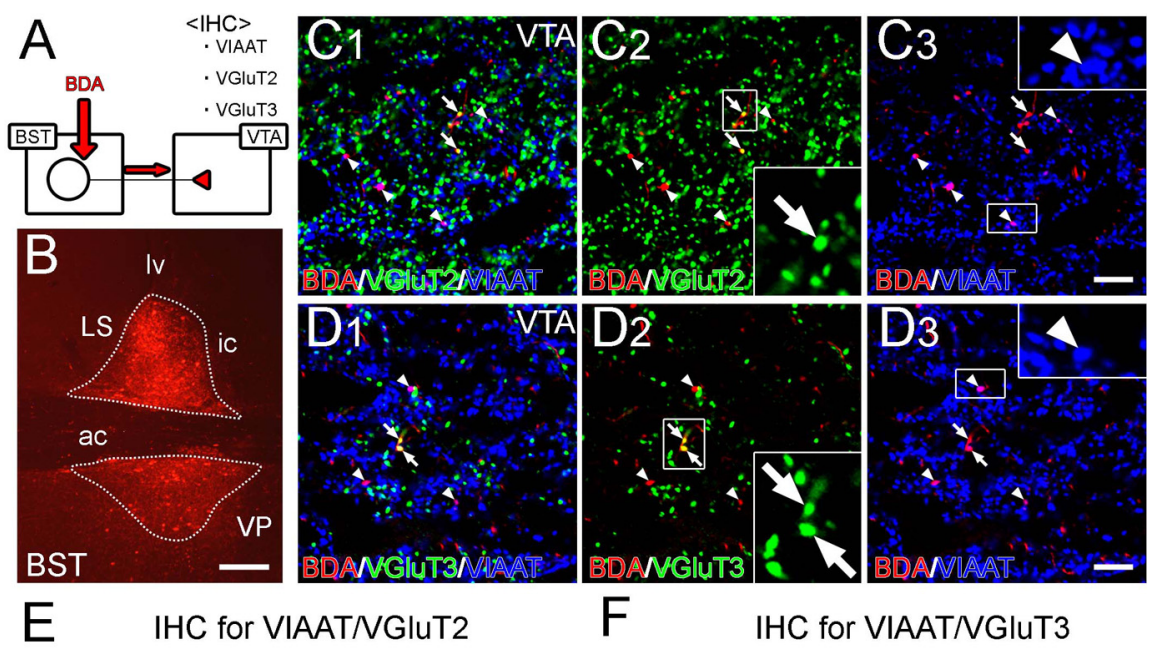

IHC for VIAATNGIUT2

BDA (+) terminals

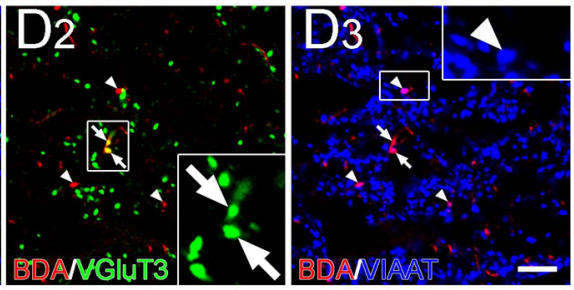

BDA (+) terminals
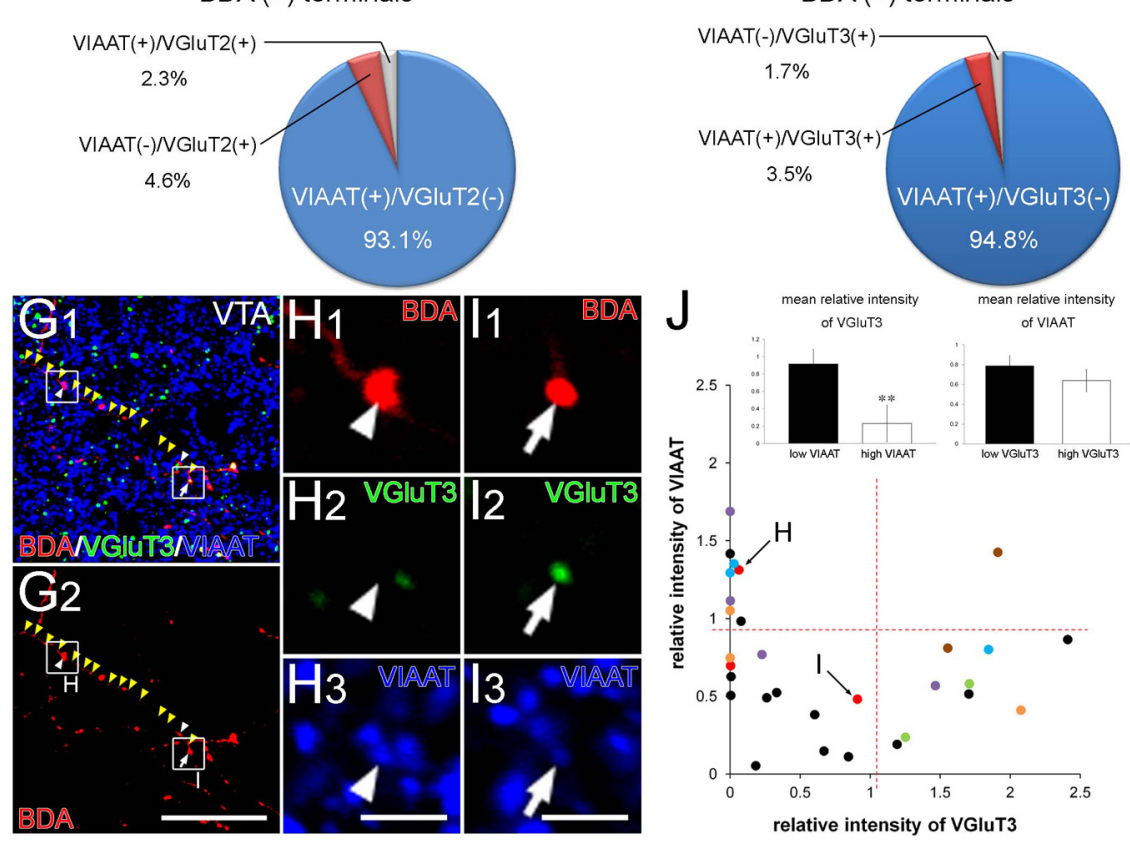

Figure 5. Combined anterograde tracer labeling and immunofluorescence showing neurochemical composition of nerve terminals projecting from the BST to the VTA. $A$, Experimental diagram. $\boldsymbol{B}$, Injection site of BDA in the BST. C, D, Triple immunofluorescence for VGluT2 (green in C) or VGluT3 (green in D) together with VIAAT (blue) and BDA (red) in the VTA. Most BDA-labeled terminals are VIAAT ${ }^{+}$(arrowheads in $\boldsymbol{C}, \boldsymbol{D}$ ) with a few VGluT2 ${ }^{+}$(arrows in $\boldsymbol{C}$ ) or VGluT3 ${ }^{+}$(arrows in $\boldsymbol{D}$ ) terminals. $\boldsymbol{E}$, $\boldsymbol{F}$, Neurochemical composition of VTA-projecting BST neuron terminals as determined from triple immunofluorescence for VGluT2/BDA/VIAAT (E) and VGluT3/BDA/VIAAT $(\boldsymbol{F})$. G-I, VGluT3 and VIAAT immunofluorescence in terminals on a single BDA-labeled BST axon in the VTA (yellow arrowheads). The two terminals indicated by the arrowhead and arrow in $\boldsymbol{G}$ are enlarged in $\boldsymbol{H}$ and $\boldsymbol{I}$, respectively, to show that a single BDA-labeled axon can produce VIAAT ${ }^{+} /$VGluT3 $^{-}(\boldsymbol{H})$ and $\mathrm{VIAAT}^{+} / \mathrm{VGluT}^{+}(\boldsymbol{I})$ terminal boutons. J, Plot showing relative intensity for VGluT3 and VIAAT in individual terminals on BDA-labeled BST axons in the VTA. Dots in the same color represents boutons derived from the same axons. Red dashed lines represent the threshold value to divide into high- and low-intensity groups. Insets show the comparison of relative fluorescence intensities for VGluT3 between low and high VIAAT groups (left) and for VIAAT between low and high VGluT3 groups (right). Error bars represent the SEM. ${ }^{* *} p<0.01$ (Mann-Whitney $U$ test). IHC, Immunohistochemistry. For other abbreviations, see Figure 2. Scale bars: $\boldsymbol{B}, 200 \mu \mathrm{m} ; \boldsymbol{C}, \boldsymbol{D}, 10 \mu \mathrm{m} ; \boldsymbol{G}, 30 \mu \mathrm{m} ; \boldsymbol{H}, \boldsymbol{I}, 5 \mu \mathrm{m}$.

\section{Partial transmitter segregation in $\mathrm{VIAAT}^{+} / \mathrm{VGluT}^{+}$ BST neurons}

More than two transmitters are often used in single neurons, and, on some occasions, they are released from distinct release sites (for review, see Sámano et al., 2012). We pursued the possibility of "transmitter segregation " in axons from GAD $67^{+} / \mathrm{VGluT3}^{+}$ BST neurons. To this end, we measured the relative immunofluorescence intensity for VGluT3 and VIAAT in individual terminals on BDA-labeled $\mathrm{VIAAT}^{+} / \mathrm{VGluT3}^{+}$axons (Fig. 5G-I). Along the axons, VIAAT was clearly detected in most terminal boutons (Fig. 5G,I), whereas VGluT3 was generally low and sometimes not detected in VIAAT ${ }^{+}$terminals (Fig. $5 G, H$ ). To evaluate this difference quantitatively, we plotted the relative intensity of individual terminals $(n=30$ terminals, seven axons from four mice; Fig. 5J), divided into high- and low-intensity groups by setting the threshold value (red broken lines), and compared the mean relative intensity of one transporter between high and low groups with that of the other (insets). In some VIAAT $^{+}$terminals, VGluT3 was very faint or below the detection threshold (dots close to or stuck on the ordinate; Fig. 5J). The mean relative intensity for VGluT3 was significantly higher in the low VIAAT group $(0.92 \pm 0.17, n=21$ terminals $)$ than in the high VIAAT group $(0.23 \pm 0.21, n=9, p=0.0061, U$ test $)$ (Fig. $5 J$, left inset). In contrast, VIAAT was detected in almost all VGluT3 ${ }^{+}$ 
terminals, and there was no significant difference in mean relative intensity for VIAAT between low $(0.79 \pm 0.11, n=20)$ and high $(0.64 \pm 0.11, n=10)$ VGluT3 groups $(p=$ $0.60, U$ test; Fig. 5J, right inset). This suggests that transmitter segregation partially occurs in axon terminals of $\mathrm{GAD} 7^{+} / \mathrm{VGluT3}^{+}$BST neurons, in which VIAAT is fundamentally loaded into individual terminals with occasional coexpression of VGluT3 in those with low VIAAT loads.

\section{Ultrastructure of BST-VTA synapses}

The morphological features of synapses formed by VTA-projecting BST neurons were examined by double-labeling preembedding immunoelectron microscopy for BDA (diffuse DAB precipitates) and VIAAT (silver-enhanced immunogold particles) (Fig. 6A,B). Synaptic contacts made by BDA-labeled terminals were found mostly on the dendritic shafts of VTA neurons (59 of 61 synapses, three mice) with the rest on the somatic surface. VIAAT $^{+}$synapses constituted $88.5 \%$ of all BDA-labeled synapses (54 of 61 synapses) (Fig. 6A). Although presynaptic filling of DAB precipitates often hindered the classification of synapses into asymmetrical and symmetrical types, we collected 16 distinguishable profiles of BDA-labeled VIAAT $^{+}$synapses. All 16 synapse profiles were judged to be symmetrical synapses (Fig. 6B, open arrowheads).

Because there were too few terminals double labeled for BDA and VGluT2 or VGluT3 for these to be quantitatively analyzed on an electron microscope, we examined the ultrastructural features of VGluT2-labeled or VGluT3-labeled VTA synapses instead. Most VGluT2-labeled synapses were judged to be asymmetrical synapses $(93.7 \%, 59$ of 63 synapses, two mice; Fig. 6C). Conversely, both symmetrical and asymmetrical synapses were encountered among VGluT3-labeled synapses. By immunoperoxidase labeling of VGluT3 (DAB precipitates) and silver-enhanced immunogold staining for VIAAT (metal particles) (four mice), we found that $88.5 \%$ of $\mathrm{VIAAT}^{-} / \mathrm{VGluT}^{+}{ }^{+}$synapses were asymmetrical (23 of 26 synapses; Fig. $6 D$ ), whereas $73.7 \%$ of $\mathrm{VIAAT}^{+} / \mathrm{VGluT3}^{+}$synapses were symmetrical (14 of 19 synapses; Fig. $6 E$ ). Because serotonergic neurons in the midbrain raphe nuclei also express VGluT3 (Fremeau et al., 2002; Gras et al., 2002; Hioki et al., 2004, 2010; Somogyi et al., 2004) and VGluT3 neurons in the raphe nuclei project to the VTA (Geisler et al., 2007; Hioki et al., 2010), we pursued the possibility that $\mathrm{VIAAT}^{-} / \mathrm{VGluT}^{+}{ }^{+}$terminals forming asymmetrical synapses in the VTA originated from serotonergic neurons. To this end, we used triple immunofluorescence for VGluT3, VIAAT, and the plasmalemmal serotonin transporter HTT (Fig. $6 F$ ). In the VTA, VGluT3 ${ }^{+}$/VIAAT $^{+}$terminals (arrowheads) and VGluT3 ${ }^{+} / \mathrm{HTT}^{+}$terminals (arrows) were distributed in a nonoverlapping manner. Immunoperoxidase labeling of VGluT3 (DAB precipitates) and silver-enhanced immunogold staining for HTT (metal
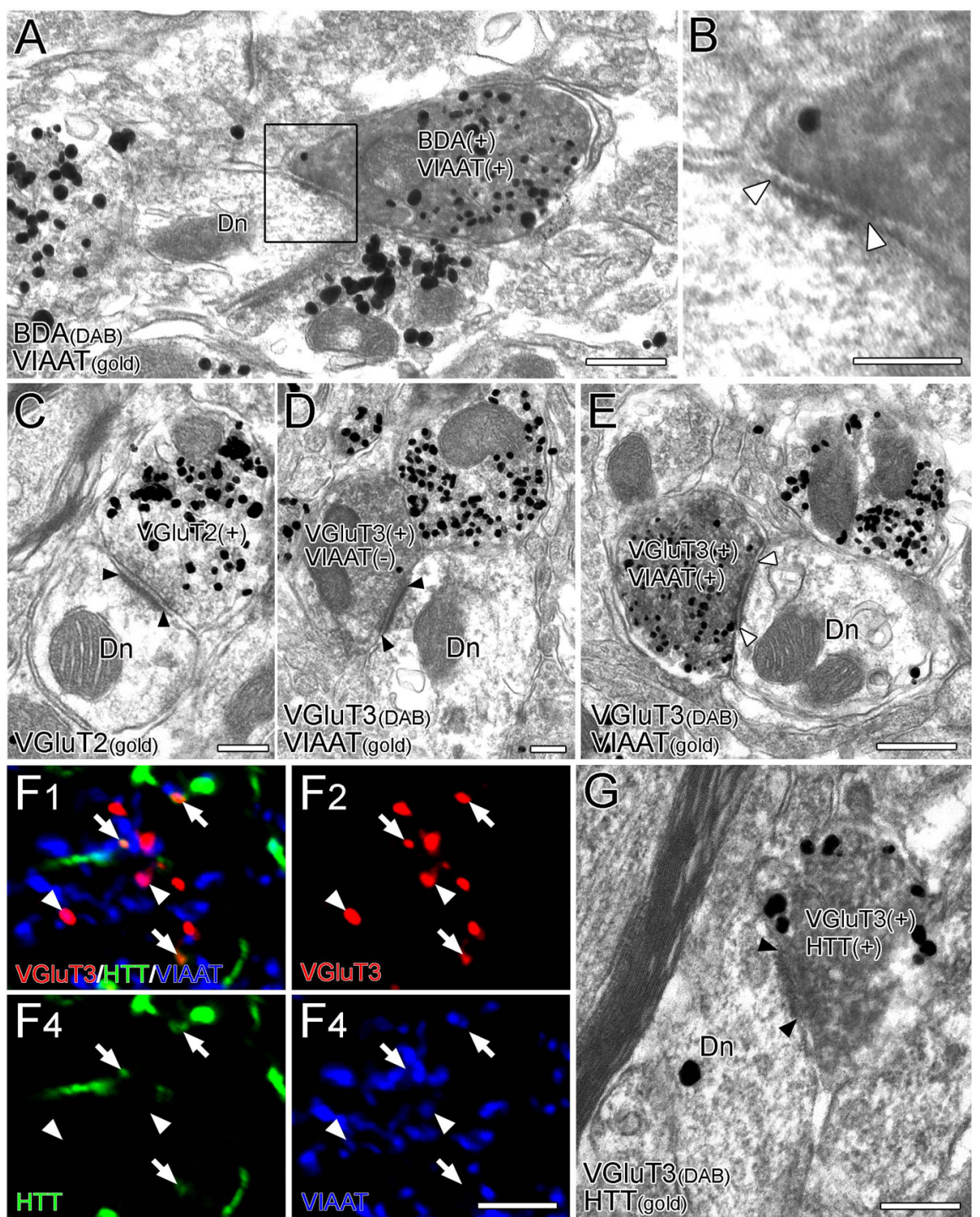

Figure 6. Morphological characterization of synapses formed by BST neurons in the VTA. $\boldsymbol{A}-\boldsymbol{E}$, Double-labeling immunoelectron minals (arrowheads) are distributed in a non-overlapping manner. G, Double-labeling immunoelectron microscopy for VGluT3 (diffuse DAB precipitates) and HTT (metal particles). Terminals colabeled for VGluT3 and HTT form asymmetrical synapses (black arrowheads). Scale bars: $\boldsymbol{A}, 500 \mathrm{~nm} ; \boldsymbol{B}-\boldsymbol{E}, \boldsymbol{G}, 200 \mathrm{~nm} ; \boldsymbol{F}, 5 \mu \mathrm{m}$. Dn, Dendrite.

particles) demonstrated that $83.3 \%$ of $\mathrm{VGluT}^{+} / \mathrm{HTT}^{+}$terminals formed asymmetrical synapses ( 15 of 18 synapses, three mice; Fig. $6 G$ ). These findings suggest that VGluT3-expressing GABAergic or serotonergic neurons mainly form symmetrical or asymmetrical synapses, respectively, in the VTA.

Thus, VTA-targeting GAD $67^{+}$BST neurons, possibly including those coexpressing VGluT3, generally form symmetrical synapses, whereas VTA-targeting VGluT2 ${ }^{+}$neurons likely form asymmetrical synapses in the VTA.

\section{BST GABAergic neurons preferentially target VTA GABAergic neurons}

The major neuronal populations in the VTA are DAergic neurons $(70-80 \%)$ and GABAergic neurons $(20-30 \%)$ with a few VGluT2-expressing glutamatergic neurons (2-3\%) (Nair- 


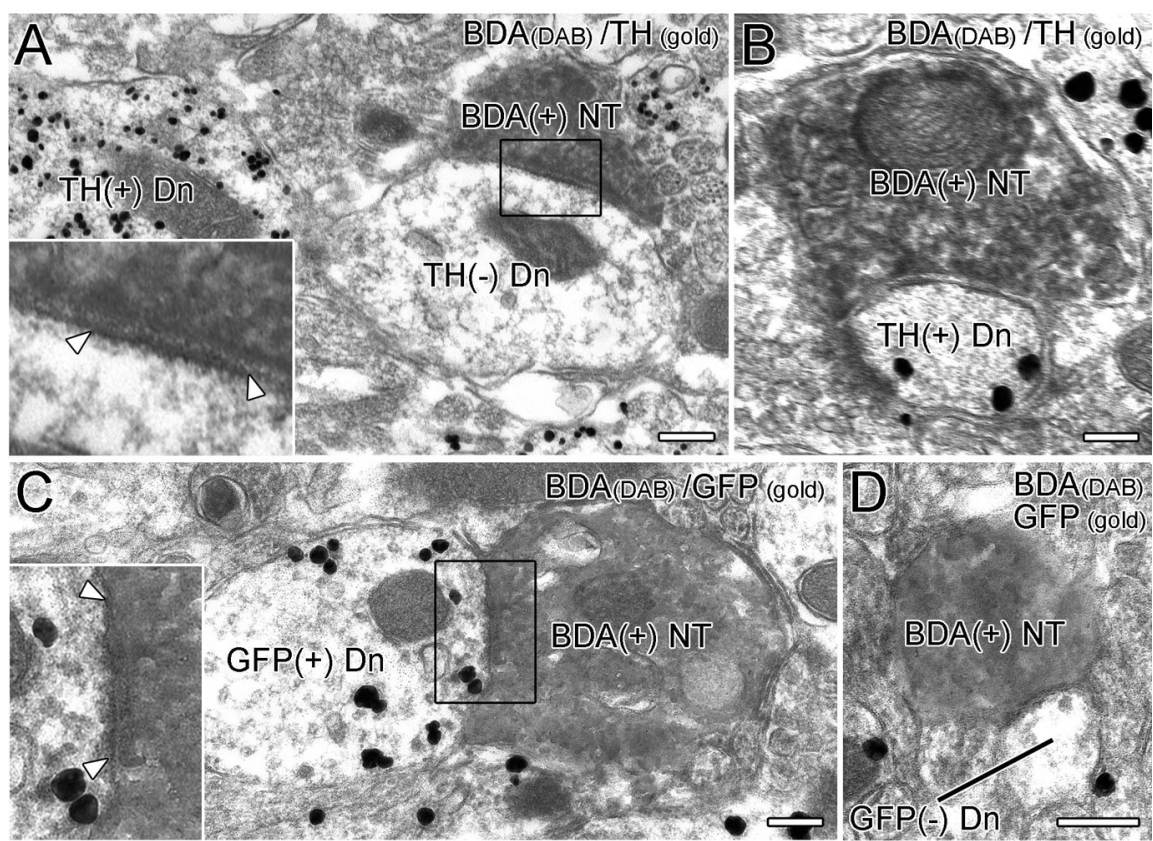

\section{E IEM for TH (C57BL/6 mice)}

synaptic contacts with $\mathrm{BDA}(+)$ terminals

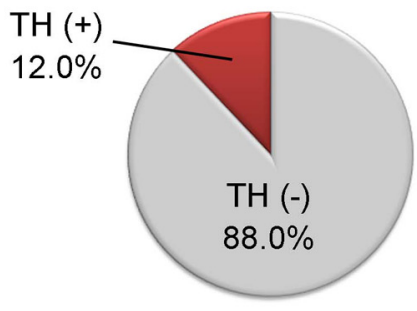

Figure 7. BST neurons forming symmetrical synapses preferentially target GABAergic neurons in the VTA. $A, B$, Double-labeling immunoelectron microscopy for BDA (diffuse DAB precipitates) and TH (metal particles) in the VTA of wild-type mice. BDA-labeled terminals form symmetrical contact (arrowheads) much more frequently on $\mathrm{TH}^{-}$dendrites $(\boldsymbol{A})$ than on $\mathrm{TH}^{+}$dendrites $(\boldsymbol{B}) . \boldsymbol{C}, \boldsymbol{D}$, Double-labeling immunoelectron microscopy (IEM) for BDA (diffuse DAB precipitates) and GFP (metal particles) in the VTA of GAD67-GFP knock-in mice. BDA-positive terminals form symmetrical synapses (arrowheads) much more frequently on GFP ${ }^{+}$ dendrites ( $\left(\right.$ ) than on GFP ${ }^{-}$dendrites (D). $\boldsymbol{E}, \boldsymbol{F}$, Proportion of GABAergic $\left(\mathrm{TH}^{-}\right.$or GFP $\left.{ }^{+}\right)$and DAergic $\left(\mathrm{TH}^{+}\right.$or GFP $\left.{ }^{-}\right)$VTA neurons targeted by BST neurons. Scale bars, $200 \mathrm{~nm}$. Dn, Dendrite; NT, nerve terminals.

Roberts et al., 2008; Sesack and Grace, 2010). To clarify the target of VTA-projecting BST neurons, we injected BDA into the BST and examined the VTA by immunoperoxidase labeling for BDA and silver-enhanced immunogold staining for $\mathrm{TH}$ to label DAergic neurons in C57BL/6 mice or for GFP to label GABAergic neurons in GAD67-GFP knock-in mice. We collected images of 25 BDA-labeled terminals from four C57BL/6 mice and 17 BDAlabeled terminals from five GAD67-GFP knock-in mice, all of which formed symmetrical synapses. We found that 22 BDAlabeled terminals made synaptic contacts with TH-negative dendrites in C57BL/6 mice (88.0\%; Fig. 7A,E). Likewise, 14 BDA-labeled terminals contacted GFP-positive dendrites in GAD67-GFP knock-in mice (82.4\%; Fig. 7C,F). Thus, BST neurons forming symmetrical synapses preferentially target VTA GABAergic neurons.

\section{Postsynaptic receptor phenotype}

In the VTA, the $\mathrm{GABA}_{\mathrm{A}}$ receptor subunits $\mathrm{GABA}_{\mathrm{A}} \alpha 1$ and $\mathrm{GABA}_{\mathrm{A}} \alpha 3$ are selectively expressed in GABAergic neurons and DAergic neurons, respectively (Tan et al., 2010). By triple immunofluorescence for GFP, GABA $\alpha 1$, and TH in GAD67-GFP knock-in mice, we confirmed that the $\mathrm{GABA}_{\mathrm{A}} \mathrm{R} \alpha 1$ subunit was detected in the perikarya and dendrites of GFP-positive GABAergic neurons but not in $\mathrm{TH}$ positive DAergic neurons (Fig. $8 A$ ). At the ultrastructural level, BDA-labeled terminals projecting from BST neurons formed symmetrical synapses on the dendritic shafts of VTA neurons, within which the $\mathrm{GABA}_{\mathrm{A}} \mathrm{R} \alpha 1$ subunit was expressed on synaptic and extrasynaptic membranes (Fig. $8 B, C$ ). Thus, BST neurons mediate their GABAergic outputs to VTA GABAergic neurons via $\mathrm{GABA}_{\mathrm{A}} \alpha 1$-containing GABA receptors.

Finally, we used double-labeling postembedding immunoelectron microscopy for VIAAT or VGluT2 in combination with $\mathrm{GABA}_{\mathrm{A}} \mathrm{R} \alpha 1$ and the AMPA-type glutamate receptor subunit GluA1. Almost all VIAAT $^{+}$synapses were judged to be symmetrical synapses (84 of 85 synapses, two mice), within which immunogold particles for $\mathrm{GABA}_{\mathrm{A}} \mathrm{R} \alpha 1$ were preferentially labeled in the postsynaptic membrane $(3.9 \pm 0.8$ particles/ $\mu \mathrm{m}$ of the synaptic membrane; $n=40$ synapses; Fig. $8 D$ ), but those for GluA1 were sparse $(0.8 \pm 0.4 ; n=44$ synapses), thus confirming the GABAergic phenotype of VIAAT $^{+}$synapses in the VTA. In contrast, almost all VGluT2 ${ }^{+}$synapses made asymmetrical contacts (113 of 120 synapses, two mice), at which immunogold particles for GluA1 were preferentially observed in the postsynaptic membrane $(4.4 \pm 0.8 ; n=58$; Fig. $8 E)$, but those for $\mathrm{GABA}_{\mathrm{A}} \mathrm{R} \alpha 1$ were sparse $(0.5 \pm 0.2 ; n=55)$. These results indicate that the postsynaptic receptor phenotype is indeed GABAergic at synapses apposing VIAAT $^{+}$terminals and glutamatergic at those apposing VGluT2 ${ }^{+}$ terminals in the VTA. With regard to $\mathrm{VGluT3}^{+}$synapses, we could not determine the receptor phenotype because of subthreshold levels of postembedding immunogold labeling for VGluT3.

\section{Discussion}

VTA DAergic neurons play crucial roles in motivational control of reward- and non-reward-related behaviors, and their activity is regulated by afferents from various sources (Grace et al., 2007; Bromberg-Martin et al., 2010; Sesack and Grace, 2010; Morikawa and Paladini, 2011). Here, we examined VTA-projecting BST neurons to better understand their composition, projections, and innervations. Based on their distinct neurochemical and anatomical properties, we characterized three distinct projections in the BST-VTA pathway.

\section{Disinhibitory projections by GABAergic BST neurons}

Consistent with the result of a previous study (Cullinan et al., 1993), 97\% of BST neurons in the anterior division of the BST expressed GAD67 mRNA. We further disclosed the following properties of VTA-projecting BST neurons: (1) 94.3\% of VTAprojecting BST neurons expressed GAD67 mRNA; (2) 93.1 or 
94.8\% (depending on the method used) of VTA-projecting BST neuron terminals expressed VIAAT; (3) they formed symmetrical synapses on to VTA neurons; and (4) $\mathrm{GABA}_{\mathrm{A}} \mathrm{R} \alpha 1$ was localized on synaptic and extrasynaptic membranes of VTA neurons innervated by BST neurons. The dense projections as well as the orchestrated molecular expression involving the synthesis, vesicular filling, and sensing of GABA provides a molecular-anatomical basis for the assertion that the main mode of BST-VTA transmission is GABAergic. Such a major inhibitory output is also true for the projection from the BST to the PVN, in which $86 \%$ of PVN-projecting BST neurons express GAD65/67 mRNA (Radley and Sawchenko, 2011).

Another important finding is that GABAergic BST neurons preferentially innervated VTA GABAergic neurons: we found that $82.4 \%$ of axon terminals from the BST innervated GABAergic $\left(\mathrm{GFP}^{+}\right)$ neurons in GAD67-GFP knock-in mice, and $88.0 \%$ targeted non-DAergic $\left(\mathrm{TH}^{-}\right)$ neurons in C57BL/6 mice. VTA GABAergic neurons are known to send inhibitory projections to local DAergic neurons and to control reward-related and aversive behaviors (Johnson and North, 1992; Omelchenko and Sesack, 2009; Tan et al., 2012; van Zessen et al., 2012). These findings suggest that BST GABAergic neurons mainly exert disynaptic disinhibition of VTA DAergic neurons via VTA GABAergic neurons. We also found that BST GABAergic neurons also target VTA DAergic neurons, although at much lower incidence.

\section{Excitatory projection by}

\section{VGluT2-expressing BST neurons}

The presence of VGluT2-expressing neurons in the BST (Hur and Zaborszky, 2005; Poulin et al., 2009) and their projection to the VTA are consistent with the results of previous studies (Geisler et al., 2007). These neurons constituted a small neuronal population in the anterior division of the BST $(\sim 3 \%)$ and lacked GAD67 or VGluT3 expression. Reflecting on the population size, $4.3 \%$ of VTA-projecting BST neurons expressed VGluT2 mRNA, and $4.6 \%$ of VTA-projecting BST neuron terminals were labeled for VGluT2. By immunoelectron microscopy, $93.7 \%$ of VGluT2 ${ }^{+}$synapses in the VTA formed the asymmetrical type of synaptic contact, a morphological feature characteristic of excitatory synapses (Gray, 1969). As expected, the cell membrane postsynaptic to VGluT2 ${ }^{+}$terminals selectively expressed AMPA-type ionotropic glutamatergic receptors. These molecular-anatomical configurations suggest that VGluT2 ${ }^{+}$afferents, which originate from various brain regions, including the BST (Geisler et al., 2007), convey purely excitatory projections to the VTA. It has been reported in rats that the BST sends monosynaptic, ionotropic glutamatergic receptor-mediated excitatory projections to, and to exert a strong excitatory influence on, VTA
DAergic neurons (Georges and Aston-Jones, 2001, 2002). Considering the scarcity of VTA-projecting VGluT2 ${ }^{+}$BST neurons and terminals compared with VTA-projecting GABAergic ones, this excitatory projection might play an additional or specific role in the modulation of the VTA, at least in mice.

\section{Modulatory inhibition by GAD67/VGluT3-coexpressing BST neurons}

Consistent with previous reports (Geisler et al., 2007; Jalabert et al., 2009), a small neuronal population in the anterior BST division expressed VGluT3 mRNA (7\%) and projected to the VTA (3.7 or 3.5\% of the VTA-projecting BST neurons or their terminals, respectively). We further revealed that all VGluT3expressing BST neurons coexpressed GAD67 mRNA, and these constituted $6.6 \%$ of the GAD67-expressing BST neurons. Of note, cotransmission of glutamate and monoamines and their segregated release sites have been suggested in DAergic and sero- 
tonergic neurons (Sulzer et al., 1998; Fremeau et al., 2002). This prompted us to test the notion of transmitter segregation in $\mathrm{GAD} 7^{+} / \mathrm{VGluT3}^{+}$BST neurons. We found that VIAAT was expressed in almost all terminals regardless of VGluT3 intensity, whereas VGluT3 substantially varied in intensity and was often missing in terminals with high VIAAT intensity. This suggests that GABA is a fundamental transmitter released from most terminals of GAD $67^{+} / \mathrm{VGluT3}^{+}$BST neurons, whereas glutamate is released from some terminals with low loads of VIAAT.

VGluT3 is coexpressed in neuronal subsets that use transmitters other than glutamate, such as cholecystokinin-containing GABAergic neurons in the neocortex and hippocampus, cholinergic neurons in the basal forebrain regions, and serotonergic/ non-serotonergic neurons in the midbrain raphe nuclei (Fremeau et al., 2002; Gras et al., 2002; Hioki et al., 2004, 2010; Somogyi et al., 2004). Unlike the situation in the BST, VGluT3expressing raphe neurons lack GAD67 mRNA expression (Hioki et al., 2010). Interestingly, we found that most VGluT3 ${ }^{+} / \mathrm{HTT}^{+}$ terminals $(83.3 \%)$ formed asymmetrical synapses in the VTA, whereas $73.7 \%$ of VGluT3 $^{+} /$VIAAT $^{+}$terminals formed symmetrical synapses. These distinct properties raise the possibility that $\mathrm{VIAAT}^{+} / \mathrm{VGluT}^{+}$symmetrical synapses release GABA as a primary or fast transmitter acting on synaptic receptors and corelease glutamate as a neuromodulator acting on perisynaptic or extrasynaptic receptors. In contrast, VGluT3 ${ }^{+} / \mathrm{HTT}^{+}$asymmetrical synapses might use glutamate as a fast synaptic transmitter and corelease serotonin as a neuromodulator. Considering the important roles of metabotropic glutamatergic receptors in the regulation of firing activity of DAergic neurons (Morikawa and Paladini, 2011), glutamate coreleased at some VIAAT ${ }^{+} /$ $\mathrm{VGluT3}^{+}$symmetrical synapses could be engaged, at least partly, in such neuromodulation.

\section{Multiple pathways for modulation of midbrain DAergic neurons}

DAergic neurons recorded in vivo display three main patterns of activity, namely, the inactive, tonic firing, and burst firing states, and the activity states are regulated by intrinsic firing properties and balanced by glutamatergic excitation and GABAergic inhibition (Grace et al., 2007; Sesack and Grace, 2010; Morikawa and Paladini, 2011). In normal animals, most DAergic neurons are tonically inhibited by GABAergic projection from the ventral pallidum (Floresco et al., 2003; Grace et al., 2007). An important regulatory pathway underlying the transition from the inactive to the tonic firing state arises from the ventral subiculum. Glutamatergic afferents from the ventral subiculum drive GABAergic neuronal firing in the nucleus accumbens, which, in turn, inhibits the ventral pallidum and thereby disinhibits DAergic neurons (Floresco et al., 2001; Grace et al., 2007). Conversely, the burst firing state of DAergic neurons is triggered by active glutamatergic and cholinergic inputs from the pedunculopontine tegmental nucleus and laterodorsal tegmental nucleus (Lodge and Grace, 2006; Grace et al., 2007; Sesack and Grace, 2010). The lateral habenula also exerts a strong inhibitory influence on midbrain DAergic neurons on aversive stimuli and reward omission (Matsumoto and Hikosaka, 2007, 2009). Therefore, DAergic VTA neurons are the target of modulation by multiple pathways, which has been interpreted as meaning that the VTA functions by integrating various and diverse bits of information (Oades and Halliday, 1987; Geisler and Zahm, 2005). In this regard, the present study will highlight that even a single pathway can modulate the VTA elaborately by working synergistically or differentially via its multiple constituent projection modes.

\section{References}

Alheid GF, Heimer L (1988) New perspectives in basal forebrain organization of special relevance for neuropsychiatric disorders: the striatopallidal, amygdaloid, and corticopetal components of substantia innominata. Neuroscience 27:1-39. CrossRef Medline

Brog JS, Salyapongse A, Deutch AY, Zahm DS (1993) The patterns of afferent innervation of the core and shell in the "accumbens" part of the rat ventral striatum: immunohistochemical detection of retrogradely transported fluoro-gold. J Comp Neurol 338:255-278. CrossRef Medline

Bromberg-Martin ES, Matsumoto M, Hikosaka O (2010) Dopamine in motivational control: rewarding, aversive, and alerting. Neuron 68:815-834. CrossRef Medline

Carr DB, Sesack SR (2000) GABA-containing neurons in the rat ventral tegmental area project to the prefrontal cortex. Synapse 38:114-123. CrossRef Medline

Cecchi M, Khoshbouei H, Javors M, Morilak DA (2002) Modulatory effects of norepinephrine in the lateral bed nucleus of the stria terminalis on behavioral and neuroendocrine responses to acute stress. Neuroscience 112:13-21. CrossRef Medline

Cullinan WE, Herman JP, Watson SJ (1993) Ventral subicular interaction with the hypothalamic paraventricular nucleus: evidence for a relay in the bed nucleus of the stria terminalis. J Comp Neurol 332:1-20. CrossRef Medline

Davis M, Whalen PJ (2001) The amygdala: vigilance and emotion. Mol Psychiatry 6:13-34. CrossRef Medline

Deyama S, Katayama T, Ohno A, Nakagawa T, Kaneko S, Yamaguchi T, Yoshioka M, Minami M (2008) Activation of the beta-adrenoceptorprotein kinase A signaling pathway within the ventral bed nucleus of the stria terminalis mediates the negative affective component of pain in rats. J Neurosci 28:7728-7736. CrossRef Medline

Fendt M, Siegl S, Steiniger-Brach B (2005) Noradrenaline transmission within the ventral bed nucleus of the stria terminalis is critical for fear behavior induced by trimethylthiazoline, a component of fox odor. J Neurosci 25:5998-6004. CrossRef Medline

Floresco SB, Todd CL, Grace AA (2001) Glutamatergic afferents from the hippocampus to the nucleus accumbens regulate activity of ventral tegmental area dopamine neurons. J Neurosci 21:4915-4922. Medline

Floresco SB, West AR, Ash B, Moore H, Grace AA (2003) Afferent modulation of dopamine neuron firing differentially regulates tonic and phasic dopamine transmission. Nat Neurosci 6:968-973. CrossRef Medline

Fremeau RT Jr, Burman J, Qureshi T, Tran CH, Proctor J, Johnson J, Zhang H, Sulzer D, Copenhagen DR, Storm-Mathisen J, Reimer RJ, Chaudhry FA, Edwards RH (2002) The identification of vesicular glutamate transporter 3 suggests novel modes of signaling by glutamate. Proc Natl Acad Sci U S A 99:14488-14493. CrossRef Medline

Fremeau RT Jr, Voglmaier S, Seal RP, Edwards RH (2004) VGLUTs define subsets of excitatory neurons and suggest novel roles for glutamate. Trends Neurosci 27:98-103. CrossRef Medline

Fukudome Y, Ohno-Shosaku T, Matsui M, Omori Y, Fukaya M, Tsubokawa H, Taketo MM, Watanabe M, Manabe T, Kano M (2004) Two distinct classes of muscarinic action on hippocampal inhibitory synapses: M2mediated direct suppression and M1/M3-mediated indirect suppression through endocannabinoid signalling. Eur J Neurosci 19:2682-2692. CrossRef Medline

Geisler S, Zahm DS (2005) Afferents of the ventral tegmental area in the rat-anatomical substratum for integrative functions. J Comp Neurol 490: 270-294. CrossRef Medline

Geisler S, Derst C, Veh RW, Zahm DS (2007) Glutamatergic afferents of the ventral tegmental area in the rat. J Neurosci 27:5730-5743. CrossRef Medline

Georges F, Aston-Jones G (2001) Potent regulation of midbrain dopamine neurons by the bed nucleus of the stria terminalis. J Neurosci 21: RC160(1-6). Medline

Georges F, Aston-Jones G (2002) Activation of ventral tegmental area cells by the bed nucleus of the stria terminalis: a novel excitatory amino acid input to midbrain dopamine neurons. J Neurosci 22:5173-5187. Medline

Grace AA, Floresco SB, Goto Y, Lodge DJ (2007) Regulation of firing of dopaminergic neurons and control of goal-directed behaviors. Trends Neurosci 30:220-227. CrossRef Medline

Gras C, Herzog E, Bellenchi GC, Bernard V, Ravassard P, Pohl M, Gasnier B, Giros B, El Mestikawy S (2002) A third vesicular glutamate transporter 
expressed by cholinergic and serotonergic neurons. J Neurosci 22:54425451. Medline

Gray EG (1969) Electron microscopy of excitatory and inhibitory synapses: a brief review. Prog Brain Res 31:141-155. CrossRef Medline

Herman JP, Cullinan WE (1997) Neurocircuitry of stress: central control of the hypothalamo-pituitary-adrenocortical axis. Trends Neurosci 20: 78-84. CrossRef Medline

Hioki H, Fujiyama F, Nakamura K, Wu SX, Matsuda W, Kaneko T (2004) Chemically specific circuit composed of vesicular glutamate transporter 3 - and preprotachykinin B-producing interneurons in the rat neocortex. Cereb Cortex 14:1266-1275. CrossRef Medline

Hioki H, Nakamura H, Ma YF, Konno M, Hayakawa T, Nakamura KC, Fujiyama F, Kaneko T (2010) Vesicular glutamate transporter 3-expressing nonserotonergic projection neurons constitute a subregion in the rat midbrain raphe nuclei. J Comp Neurol 518:668-686. CrossRef Medline

Hur EE, Zaborszky L (2005) Vglut2 afferents to the medial prefrontal and primary somatosensory cortices: a combined retrograde tracing in situ hybridization study. J Comp Neurol 483:351-373. CrossRef Medline

Ichikawa R, Yamasaki M, Miyazaki T, Konno K, Hashimoto K, Tatsumi H, Inoue Y, Kano M, Watanabe M (2011) Developmental switching of perisomatic innervations from climbing fibers to basket cell fibers in cerebellar Purkinje cells. J Neurosci 31:16916-16927. CrossRef Medline

Jalabert M, Aston-Jones G, Herzog E, Manzoni O, Georges F (2009) Role of the bed nucleus of the stria terminalis in the control of ventral tegmental area dopamine neurons. Prog Neuropsychopharmacol Biol Psychiatry 33:1336-1346. CrossRef Medline

Johnson SW, North RA (1992) Opioids excite dopamine neurons by hyperpolarization of local interneurons. J Neurosci 12:483-488. Medline

Lodge DJ, Grace AA (2006) The laterodorsal tegmentum is essential for burst firing of ventral tegmental area dopamine neurons. Proc Natl Acad Sci U S A 103:5167-5172. CrossRef Medline

Matsumoto M, Hikosaka O (2007) Lateral habenula as a source of negative reward signals in dopamine neurons. Nature 447:1111-1115. CrossRef Medline

Matsumoto M, Hikosaka O (2009) Two types of dopamine neuron distinctly convey positive and negative motivational signals. Nature 459: 837-841. CrossRef Medline

Miura E, Fukaya M, Sato T, Sugihara K, Asano M, Yoshioka K, Watanabe M (2006) Expression and distribution of JNK/SAPK-associated scaffold protein JSAP1 in developing and adult mouse brain. J Neurochem 97: 1431-1446. CrossRef Medline

Miyazaki T, Fukaya M, Shimizu H, Watanabe M (2003) Subtype switching of vesicular glutamate transporters at parallel fibre-Purkinje cell synapses in developing mouse cerebellum. Eur J Neurosci 17:2563-2572. CrossRef Medline

Morikawa H, Paladini CA (2011) Dynamic regulation of midbrain dopamnine neuron activity: intrinsic, synaptic, and plasticity mechanisms. Neuroscience 198:95-111. CrossRef Medline

Nair-Roberts RG, Chatelain-Badie SD, Benson E, White-Cooper H, Bolam JP, Ungless MA (2008) Stereological estimates of dopaminergic, GABAergic and glutamatergic neurons in the ventral tegmental area, substantia nigra and retrorubral field in the rat. Neuroscience 152: 1024-1031. CrossRef Medline

Nijsen MJ, Croiset G, Diamant M, De Wied D, Wiegant VM (2001) CRH signaling in the bed nucleus of the stria terminalis is involved in stressinduced cardiac vagal activation in conscious rats. Neuropsychopharmacology 24:1-10. CrossRef Medline

Oades RD, Halliday GM (1987) Ventral tegmental (A10) system: neurobiology. 1. Anatomy and connectivity. Brain Res 434:117-165. Medline

Omelchenko N, Sesack SR (2009) Ultrastructural analysis of local collaterals of rat ventral tegmental area neurons: GABA phenotype and synapses onto dopamine and GABA cells. Synapse 63:895-906. CrossRef Medline

Poulin JF, Arbour D, Laforest S, Drolet G (2009) Neuroanatomical characterization of endogenous opioids in the bed nucleus of the stria terminalis. Prog Neuropsychopharmacol Biol Psychiatry 33:1356-1365. CrossRef Medline

Radley JJ, Sawchenko PE (2011) A common substrate for prefrontal and hippocampal inhibition of the neuroendcrine stress response. J Neurosci 31:9683-9695. CrossRef Medline

Sámano C, Cifuentes F, Morales MA (2012) Neurotransmitter segregation: functional and plastic implications. Prog Neurobiol 97:277-287. CrossRef Medline

Schultz W, Dayan P, Montague PR (1997) A neural substrate of prediction and reward. Science 275:1593-1599. CrossRef Medline

Sesack SR, Grace AA (2010) Cortico-basal ganglia reward network: microcircuitry. Neuropsychopharmacology 35:27-47. CrossRef Medline

Somogyi J, Baude A, Omori Y, Shimizu H, El Mestikawy S, Fukaya M, Shigemoto R, Watanabe M, Somogyi P (2004) GABAergic basket cells expressing cholecystokinin contain vesicular glutamate transporter type 3 (VGLUT3) in their synaptic terminals in hippocampus and isocortex of the rat. Eur J Neurosci 19:552-569. CrossRef Medline

Steffensen SC, Svingos AL, Pickel VM, Henriksen SJ (1998) Electrophysiological characterization of GABAergic neurons in the ventral tegmental area. J Neurosci 18:8003-8015. Medline

Sullivan GM, Apergis J, Bush DE, Johnson LR, Hou M, Ledoux JE (2004) Lesions in the bed nucleus of the stria terminalis disrupt corticosterone and freezing responses elicited by a contextual but not by a specific cueconditioned fear stimulus. Neuroscience 128:7-14. CrossRef Medline

Sulzer D, Joyce MP, Lin L, Geldwert D, Haber SN, Hattori T, Rayport S (1998) Dopamine neurons make glutamatergic synapses in vitro. J Neurosci 18:4588-4602. Medline

Takamori S (2006) VGLUTs: "exciting" times for glutamatergic research? Neurosci Res 55:343-351. CrossRef Medline

Takasaki C, Yamasaki M, Uchigashima M, Konno K, Yanagawa Y, Watanabe M (2010) Cytochemical and cytological properties of perineuronal oligodendrocytes in the mouse cortex. Eur J Neurosci 32:1326-1336. CrossRef Medline

Tamamaki N, Yanagawa Y, Tomioka R, Miyazaki J, Obata K, Kaneko T (2003) Green fluorescent protein expression and colocalization with calretinin, parvalbumin, and somatostatin in the GAD67-GFP knock-in mouse. J Comp Neurol 467:60-79. CrossRef Medline

Tan KR, Brown M, Labouèbe G, Yvon C, Creton C, Fritschy JM, Rudolph U, Lüscher C (2010) Neural bases for addictive properties of benzodiazepines. Nature 463:769-774. CrossRef Medline

Tan KR, Yvon C, Turiault M, Mirzabekov JJ, Doehner J, Labouèbe G, Deisseroth K, Tye KM, Lüscher C (2012) GABA neurons of the VTA drive conditioned place aversion. Neuron 73:1173-1183. CrossRef Medline

Van Bockstaele EJ, Pickel VM (1995) GABA-containing neurons in the ventral tegmental area project to the nucleus accumbens in rat brain. Brain Res 682:215-221. CrossRef Medline

van Zessen R, Phillips JL, Budygin EA, Stuber GD (2012) Activation of VTA GABA neurons disrupts reward consumption. Neuron 73:1184-1194. CrossRef Medline

Walker DL, Davis M (1997) Double dissociation between the involvement of the bed nucleus of the stria terminalis and the central nucleus of the amygdala in startle increases produced by conditioned versus unconditioned fear. J Neurosci 17:9375-9383. Medline

Watanabe M, Fukaya M, Sakimura K, Manabe T, Mishina M, Inoue Y (1998) Selective scarcity of NMDA receptor channel subunits in the stratum lucidum (mossy fibre-recipient layer) of the mouse hippocampal CA3 subfield. Eur J Neurosci 10:478-487. CrossRef Medline

Yamasaki M, Matsui M, Watanabe M (2010) Preferential localization of muscarinic M1 receptor on dendritic shaft and spine of cortical pyramidal cells and its anatomical evidence for volume transmission. J Neurosci 30:4408-4418. CrossRef Medline

Yamasaki M, Miyazaki T, Azechi H, Abe M, Natsume R, Hagiwara T, Aiba A, Mishina M, Sakimura K, Watanabe M (2011) Glutamate receptor $\delta 2$ is essential for input pathway-dependent regulation of synaptic AMPAR contents in cerebellar Purkinje cells. J Neurosci 31:3362-3374. CrossRef Medline

Yamazaki M, Fukaya M, Hashimoto K, Yamasaki M, Tsujita M, Itakura M, Abe M, Natsume R, Takahashi M, Kano M, Sakimura K, Watanabe M (2010) TARPs gamma-2 and gamma-7 are essential for AMPA receptor expression in the cerebellum. Eur J Neurosci 31:2204-2220. CrossRef Medline 